\title{
Electron transfer reactions between chloroaurate(III) complexes and various inorganic and organic reducing agents in acid medium - a brief review
}

\author{
Biswajit Pal ${ }^{a *}$, Pratik K. Sen ${ }^{b}$ and Kalyan K. Sen Gupta ${ }^{b *}$ \\ E-mail : palbiswajit@yahoo.com \\ ${ }^{b}$ Department of Chemistry, Jadavpur University, Kolkata-700 032; India \\ Manuscript received 9 December 2005, revised 2 May 2006, accepted 12 May 2006
}

${ }^{a}$ Department of Chemistrý, St. Paul's C. M. College, 33/1. Raja Rammohan Roy Sarani, Kolkata-700 009, India

\begin{abstract}
The review narrates the electron transfer reactions of some chloroaurate(III) complexes in acid medium reported since 1970 onwards. The reactions involving inorganic substrates and gold(III) were studied mostly in $\mathrm{HCl}$ medium whereas the oxidations of different organic substrates were investigated in sodium acetate-acetic acid buffer medium. Increase in $\left[\mathrm{H}^{+}\right]$decreases the rate of reactions. At higher concentrations of $\left[\mathrm{H}^{+}\right]\left(\mathrm{ca} . \geq 0.5 \mathrm{~mol} \mathrm{dm}^{-3}\right), \mathrm{AuCl}_{4}^{-}$ or $\mathrm{HAuCl}_{4}$ is the reactive gold(III) species whereas when the reactions were studied in much lower acidities of $\left[\mathrm{H}^{+}\right]$ $\left(<0.5 \mathrm{~mol} \mathrm{dm}^{-3}\right.$ ) or in sodium acetate-acetic acid buffer medium, $\mathrm{AuCl}_{4}^{-}, \mathrm{AuCl}_{3}\left(\mathrm{OH}_{2}\right)$ and $\mathrm{AuCl}_{3}(\mathrm{OH})^{-}$are the reactive species which oxidize the substrates. Kinetic evidence for the participation of $\mathrm{AuCl}_{4}^{-}, \mathrm{AuCl}_{3}\left(\mathrm{OH}_{2}\right)$ and $\mathrm{AuCl}_{3}\left(\mathrm{OH}^{-}\right.$ is provided. The reactivity of these different gold(III) species follow the order : $\mathrm{AuCl}_{3}(\mathrm{OH})^{-}>\mathrm{AuCl}_{3}\left(\mathrm{OH}_{2}\right)>\mathrm{AuCl}_{4}{ }^{-}$. Influence of ionic strength was noticed in the oxidations of some inorganic and organic compounds by gold(III). The rates in the presence of different salts like $\mathrm{NaCl}, \mathrm{NaClO}_{4}$ and $\mathrm{Na}_{2} \mathrm{SO}_{4}$ at constant ionic strength was found to be same in the oxidations of a number of inorganic compounds indicating that anions do not have any influence on the rate. The rates were found to depend not only on the ionic strength but also on the concentration and nature of the cations. The pseudo-first-order rate constant increases in the order $\mathrm{Li}^{+}<\mathrm{Na}^{+}<\mathrm{K}^{+}<\mathrm{Rb}^{+}<\mathrm{Cs}^{+}$in the oxidation of a number of inorganic substrates. The reactions exhibit diverse mechanistic behavior. Kinetic and mechanistic features associated with such reactions have been discussed and analyzed. An attempt has been made to correlate mainly our experimental observations.
\end{abstract}

Keywords : Electron transfer reactions, auric complexes, reducing agents.

\section{Introduction}

Gold is widely distributed in nature and the chemistry of gold remains an active research area ${ }^{1(a)}$. Gold is not essential for any living organism though some plants concentrate the element ${ }^{1(b)}$. Gold is known to exist in different oxidation states such as $+1,+2,+3,(+4)$ and $(+5)$ for which the electronic configurations are $\underline{d}^{10}, d^{9}, \underline{d}^{8}$, $\left(d^{7}\right)$ and $\left(d^{6}\right)$, respectively. Of these different states, the underlined states are the most important and the states in the parenthesis are unconfirmed. Complexes of different oxidation states of gold have been discussed and incorporated by Puddephatt ${ }^{2}$ and other workers ${ }^{3}$.

Gold(III) forms a number of stable complex ions. The anionic complexes ${ }^{4}$ like $\mathrm{AuF}_{4}^{-}, \mathrm{AuCl}_{4}^{-}, \mathrm{Au}(\mathrm{CN})_{4}^{-}$and $\mathrm{Au}\left(\mathrm{NO}_{3}\right)_{4}^{-}$and four coordinated cationic complexes ${ }^{5}$ such as $\left[\mathrm{AuCl}_{2} \mathrm{py}_{2}\right] \mathrm{Cl},\left[\mathrm{Au}(\mathrm{phen})_{2} \mathrm{Cl}_{2}\right] \mathrm{Cl}$ and $\left[\mathrm{Au}(\text { bipy })_{2} \mathrm{Cl}_{2}\right] \mathrm{Cl}$ have been reported in the literature.
The lowest and highest coordination number found in coordination compounds of gold are two and six respectively with the intermediate number four being the most frequent for gold(III) and two for gold(I) compounds. A wider range of coordination numbers (two to twelve) exists in organometallic cluster compounds.

Some gold(I) compounds are biologically active and used as anti inflammatory drugs in the treatment of rheumatoid arthritis ${ }^{6-9}$. Several gold(III) compounds were also used earlier in the treatment of tuberculosis ${ }^{10}$ whereas a few gold(III) complexes are found to have antitumour activity ${ }^{11,12}$. Again such gold compounds are found to have severe toxic effects ${ }^{13,14}$ on human health such as kidney damage and blood disorders. Such toxic effects are presumed to be related to gold(I)-gold(III) oxidation in vivo followed by gold(III)-biomolecule interactions ${ }^{15(a)}$. Redox and ligand exchange reactions of potential gold(I) and gold(III)-cyanide metabolites under biomimetic con- 
Pal et al. : Electron transfer reactions between chloroaurate(III) complexes etc.

ditions have been reported ${ }^{15(b)}$. There are reports ${ }^{15(c)}$ on the investigation of a metal-centered porphyrine in nonpolar solvent where a long-lived charge separated state of the product has been identified. In view of all the above findings, kinetic studies on the reduction of $\mathrm{Au}^{\mathrm{III}}$ by various inorganic as well as organic compounds have become increasingly interesting. This has become important from another point of view that gold(III) can behave both as a one-electron and a two-electron transfer oxidant.

Considerable amount of work has been done $\mathrm{e}^{16-30}$ on the oxidations of different reducing substrates by chloroaurate(III) complexes under different experimental conditions but no attempt has been made till date to record the progress in this field. This necessitates a review of redox reactions involving chloroaurate(III) complexes and different inorganic and organic substrates and an attempt has been made to analyze and correlate the results.

\section{Results}

The standard reduction potentials relating to đifferent oxidation states of gold at $298.1 \mathrm{~K}$ have been reported ${ }^{31,32}$. The values commonly used are mentioned below.

$$
\begin{array}{cc}
\text { Reaction } & E^{\mathrm{o}},(\mathrm{V}) \\
\mathrm{Au}^{+}+\mathrm{e} \rightleftharpoons \mathrm{Au} & 1.68 \\
\mathrm{Au}^{2+}+\mathrm{e} \rightleftharpoons \mathrm{Au}^{+} & >1.29 \\
\mathrm{Au}^{3+}+\mathrm{e} \rightleftharpoons \mathrm{Au}^{2+} & <1.29 \\
\mathrm{Au}^{3+}+2 \mathrm{e} \rightleftharpoons \mathrm{Au}^{+} & 1.401 \\
\mathrm{Au}^{3+}+3 \mathrm{e} \rightleftharpoons \mathrm{Au} & 1.498
\end{array}
$$

The standard reduction potentials are highly dependent on the ligands attached and those where ligands (L) like $\mathrm{H}_{2} \mathrm{O}, \mathrm{Cl}^{-}, \mathrm{Br}^{-}, \mathrm{I}^{-}, \mathrm{CN}^{-}$and $\mathrm{SCN}^{-}$are attached to the metal with different oxidation states have been reported ${ }^{33}$.

\section{Different oxidizing species of gold(III) :}

Gold(III) complexes are stable mainly in acid medium. However, gold(III) oxidations of different substrates which have been studied in acidic medium are kinetically dissimilar and characterized by variety of reaction pathways. A number of studies reveal that the square planar $\mathrm{AuCl}_{4}^{-}$ ion undergoes fast hydrolysis ${ }^{4(b), 34,35}$ and produces two other $\mathrm{Au}^{\mathrm{III}}$ species, namely, $\mathrm{AuCl}_{3}\left(\mathrm{H}_{2} \mathrm{O}\right)$ and $\mathrm{AuCl}_{3}(\mathrm{OH})^{-}$. Thus in solution of chloroauric acid, four gold(III) species, viz. $\mathrm{HAuCl}_{4}, \mathrm{AuCl}_{4}{ }^{-}, \mathrm{AuCl}_{3}\left(\mathrm{H}_{2} \mathrm{O}\right)$ and $\mathrm{AuCl}_{3}(\mathrm{OH})^{-}$ coexist and render the system complicated. Theses spe- cies are involved in the following equilibria.

$$
\begin{aligned}
& \mathrm{HAuCl}_{4} \stackrel{K_{1} \rightleftharpoons \mathrm{H}^{+}+\mathrm{AuCl}_{4}^{-}}{\rightleftharpoons} \\
& \mathrm{AuCl}_{4}^{-}+\mathrm{H}_{2} \mathrm{O} \stackrel{K_{2} \rightleftharpoons \mathrm{AuCl}_{3}\left(\mathrm{OH}_{2}\right)+\mathrm{Cl}^{-}}{\rightleftharpoons} \mathrm{KuCl}_{3}\left(\mathrm{OH}_{2}\right) \stackrel{K_{3} \rightleftharpoons \mathrm{AuCl}_{3}(\mathrm{OH})^{-}+\mathrm{H}^{+}}{\rightleftharpoons}
\end{aligned}
$$

where $K_{1}, K_{2}$ and $K_{3}$ are $1.0,9.5 \times 10^{-6}$, and 0.25 . respectively at $298 \mathrm{~K}^{26,34,35}$. The relative concentration of each of the above species will be controlled by the $\mathrm{pH}$ and the concentration of $\mathrm{Cl}^{-}$ion in the solution.

\section{Oxidation of inorganic compounds by gold(III) :}

The kinetics of oxidation of a few compounds of metals such as iron(II) ${ }^{16}$, platinum(II) ${ }^{16,36}$ and thalium(I) ${ }^{37}$ have been reported. Moodley and Nicol studied ${ }^{16}$ the reduction of gold(III) by iron(II) chloride amperometrically under the condition $\left[\mathrm{Au}^{\mathrm{III}}\right] \gg\left[\mathrm{Fe}^{\mathrm{Il}}\right]$. The influence of $\mathrm{H}^{+}$ion was studied in the acid range $(0.05-1.0) \mathrm{mol}$ $\mathrm{dm}^{-3} \mathrm{HClO}_{4}$ at $\left[\mathrm{Cl}^{-}\right]=1.0 \mathrm{~mol} \mathrm{dm}^{-3}$ and $I=1.0 \mathrm{~mol}$ $\mathrm{dm}^{-3}$ and a negligible $\mathrm{H}^{+}$ion dependence has been observed. Moreover, the dependence on $\mathrm{Cl}^{-}$ion was studied in the range of $\left[\mathrm{Cl}^{-}\right]=(0.05-1.0) \mathrm{mol} \mathrm{dm}^{-3}$ at $\left[\mathrm{H}^{+}\right]$ $=1.0 \mathrm{~mol} \mathrm{dm}^{-3}$ and the observed behavior was accounted for by a mechanism consisting of parallel paths involving $\mathrm{Fe}^{2+}$ and $[\mathrm{FeCl}]^{+}$.

$$
\mathrm{Au}^{\mathrm{III}}+\mathrm{Fe}^{\mathrm{II}} \underset{k_{-1}}{\rightleftharpoons} \mathrm{Au}^{\mathrm{II}}+\mathrm{Fe}^{\mathrm{III}}
$$

$$
\mathrm{Au}^{\mathrm{II}}+\mathrm{Fe}^{\mathrm{II}} \stackrel{k_{2}}{\longrightarrow} \mathrm{Au}^{\mathrm{I}}+\mathrm{Fe}^{\mathrm{III}}
$$

On the assumption that the steady state approximation for intermediate gold(II) is valid, the following rate expression was deduced.

$$
-d\left[\mathrm{Fe}^{\mathrm{II}}\right] / d t=\frac{2 k_{1} k_{2}\left[\mathrm{Fe}^{\mathrm{II}}\right]^{2}\left[\mathrm{Au}^{\mathrm{III}}\right]}{k_{-1}\left[\mathrm{Fe}^{\mathrm{II}}\right]+k_{2}\left[\mathrm{Fe}^{\mathrm{II}}\right]}
$$

The reduction of gold(III) by $\mathrm{PtCl}_{4}{ }^{2-}$ has also been studied by Moodley and $\mathrm{Nicol}^{16}$ spectrophotometrically and the reaction involves a complementary two electron transfer step.

$$
\mathrm{Au}^{\mathrm{III}}+\mathrm{Pt}^{\mathrm{II}} \underset{\text { Transition state }}{\stackrel{k_{3}}{\longrightarrow}}(\mathrm{X}) \underset{\mathrm{Au}^{\mathrm{I}}}{\longrightarrow}+\mathrm{Pt}^{\mathrm{IV}}
$$


The rate expression is

$$
-d\left[\mathrm{Au}^{\mathrm{III}}\right] / d t=k_{3}\left[\mathrm{Au}^{\mathrm{III}}\right]\left[\mathrm{Pt}^{\mathrm{II}}\right]
$$

No effect of $\mathrm{Cl}^{-}$ion on the rate was observed, however, the increase of both the ionic strength and $\mathrm{pH}$ enhance the reaction rate.

Mechanism for the oxidation of $\mathrm{PI}^{\mathrm{II}}(\mathrm{CN})_{4}{ }^{2-}$ by gold(III) has been studied ${ }^{36(\text { a) }}$ by the use of stopped-flow and conventional spectrophotometric method, where the different gold(III) species viz. $\mathrm{AuCl}_{4}^{-}, \mathrm{AuCl}_{3}\left(\mathrm{OH}_{2}\right)$ and $\mathrm{AuCl}_{3}(\mathrm{OH})^{-}$were involved depending on the experimental conditions. Redox reactions are proposed to take place via chloride-bridged inner-sphere mechanisms. The steps of the reaction are as follows.

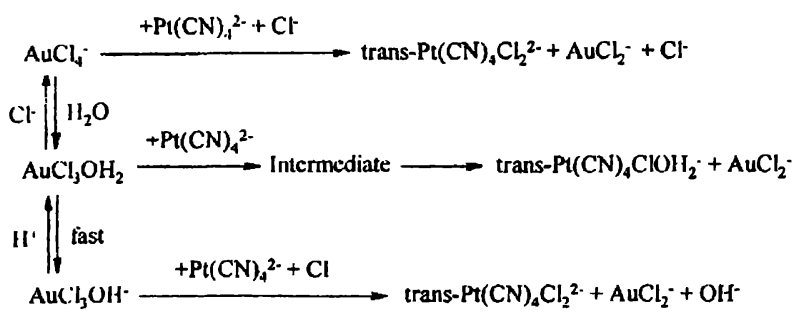

In a $10^{-5} \mathrm{~mol} \mathrm{dm}{ }^{-3}$ gold(III) solution with $\left[\mathrm{Cl}^{-}\right] \leq 2 \times 10^{-4}$ mol dm $\mathrm{dm}^{-3}$ and $\mathrm{pH}=0$, oxidation by $\mathrm{AuCl}_{3}\left(\mathrm{OH}_{2}\right)$ is predominant and reaction takes place via the chloride bridged intermediate $\left[\mathrm{H}_{2} \mathrm{O} \ldots \mathrm{Pt}(\mathrm{CN})_{4}-\mathrm{Cl}-\mathrm{AuCl}_{2} \ldots \mathrm{OH}_{2}{ }^{2-}\right]$. However, at $\left[\mathrm{Cl}^{-}\right] \geq 0.25 \mathrm{~mol} \mathrm{dm}^{-3}$ and $\mathrm{pH} \sim 5$, the oxidation occurs by $\mathrm{AuCl}_{4}^{-}$and $\mathrm{AuCl}_{3}(\mathrm{OH})^{-}$via parallel paths. In such cases, the $\mathrm{Cl}^{-}$assistance of the redox reaction has been accounted for by the formation of intermediates of the type $\mathrm{Cl} \ldots \mathrm{Pt}(\mathrm{CN})_{4}-\mathrm{Cl}-\mathrm{AuCl}_{2} \ldots \mathrm{X}^{4-}, \mathrm{X}=$ $\mathrm{Cl}^{-}, \mathrm{OH}^{-}$. In contrast to this study, the investigation made by Peloso ${ }^{36(\mathrm{~b})}$ showed only $\mathrm{AuCl}_{4}{ }^{-}$species to be involved in the oxidation of platinum(II).

The complementary reaction between $\mathrm{Tl}^{\mathrm{I}}$ and $\mathrm{AuCl}_{4}^{-}$ has been investigated by Gidd et al. ${ }^{37}$ in $3.0 \mathrm{~mol} \mathrm{dm}^{-3}$ $\mathrm{HCl}$ medium. Under the experimental conditions, the active species of oxidant and reductant were found to be $\mathrm{HAuCl}_{4}$ and $\mathrm{TlCl}_{2}^{-}$respectively.

Kinetics of the oxidation of different compounds of nitrogen ${ }^{17-19}$, phosphorous ${ }^{20}$, arsenic ${ }^{21}$, antimony ${ }^{22}$, and sulphur $^{24}$ by gold(II) have been studied spectrophotometrically in hydrochloric acid medium. The reaction of hydrazinium ion $\mathrm{N}_{2} \mathrm{H}_{5}{ }^{+}$with $\mathrm{Au}^{\text {IIl } 17}$ is first order in both [ $\left.\mathrm{Au}^{\mathrm{III}}\right]$ and $\left[\mathrm{N}_{2} \mathrm{H}_{5}{ }^{+}\right]$. Hydrogen ion inhibits the rate of oxidation. The following steps are proposed.

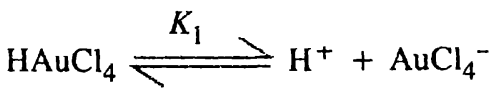

$$
\begin{aligned}
& \mathrm{N}_{2} \mathrm{H}_{5}{ }^{+}+\mathrm{AuCl}_{4}^{-} \stackrel{k_{4}}{\longrightarrow} \text { products }
\end{aligned}
$$

The products $\mathrm{N}_{2}$ and $\mathrm{NH}_{4}{ }^{+}$are formed by one electron transfer oxidation process whereby gold(III) is initially reduced to gold(II). This is supported by the decrease in reaction rate $(-72 \%)$ in $5.6 \%(w / v)$ acrylamide.

The rate expression is

$$
-d\left[\mathrm{Au}^{\mathrm{III}}\right] / d t=\frac{k_{4} K_{1}\left[\mathrm{Au}^{\mathrm{III}}\right]\left[\mathrm{N}_{2} \mathrm{H}_{5}{ }^{+}\right]}{K_{1}+\left[\mathrm{H}^{+}\right]}
$$

The value of $K_{1}$ was found to be 1.01. However, the same $K_{1}$ from distribution studies ${ }^{35}$ of $\mathrm{HAuCl}_{4}$ between water and diethyl ether was 1.35 and from another kinetic studies ${ }^{16}$ by Moodley and Nicol in hydrochloric acid medium was 1.1 .

The oxidation of hydroxylammonium ion by gold(III) was studied in $\mathrm{HCl}^{18(\mathrm{a})}$ as well as $\mathrm{HClO}_{4}{ }^{18(\mathrm{~b})}$ media. The stoichiometry of the reaction ${ }^{18(\mathrm{a})}$ in $\mathrm{HCl}$ medium is

$$
\begin{aligned}
& \mathrm{AuCl}_{4}{ }^{-}+ 2 \mathrm{NH}_{3} \mathrm{OH}^{+} \longrightarrow \\
& \mathrm{AuCl}_{4}{ }^{3-}+\mathrm{N}_{2}+4 \mathrm{H}^{+}+2 \mathrm{H}_{2} \mathrm{O}
\end{aligned}
$$

The reaction takes place through the intermediate formation of free radical followed by its decomposition to give $\mathrm{N}_{2}$ and is in keeping with the observation ${ }^{18(\mathrm{c})}$ made during the oxidation of this substrate by $\mathrm{Ni}^{\mathrm{IV}}$.

$$
\begin{aligned}
& 2 \mathrm{Au}^{\mathrm{III}}+\mathrm{NH}_{3} \mathrm{OH}^{+} \longrightarrow \\
& \mathrm{Au}^{\mathrm{II}}+\mathrm{NH}_{2} \mathrm{O}^{\bullet}+2 \mathrm{H}^{+} \text {) } \\
& 2 \mathrm{NH}_{2} \mathrm{O}^{\bullet} \longrightarrow \mathrm{N}_{2}+3 \mathrm{H}_{2} \mathrm{O} \\
& 2 \mathrm{Au}^{\mathrm{II}} \longrightarrow \mathrm{Au}^{\mathrm{III}}+\mathrm{Au}^{\mathrm{I}}
\end{aligned}
$$

On the other hand when the reaction was studied ${ }^{18(b)}$ in $\mathrm{HClO}_{4}$ medium, the reaction has been shown to occur as follows.

$$
\begin{aligned}
& 2 \mathrm{AuCl}_{4}{ }^{-}+2 \mathrm{NH}_{3} \mathrm{OH}^{+} \longrightarrow \\
& 2 \mathrm{AuCl}_{4}{ }^{3-}+\mathrm{N}_{2} \mathrm{O}+6 \mathrm{H}^{+}+\mathrm{H}_{2} \mathrm{O}
\end{aligned}
$$

The stoichiometry of the reaction in perchloric acid medium $^{18(b)}$ was studied in which gold(III) was in excess to that of the substrate whereas the same was determined in excess hydroxylammonium concentration in $\mathrm{HCl}$ medium $^{18(a)}$. Consequently even if HNO is formed (via two electron transfer oxidation mechanism) in the ratedetermining step in $\mathrm{HClO}_{4}$ medium, in the presence of excess substrate the possibility of formation of $\mathrm{N}_{2}$ cannot 
Pal et al. : Electron transfer reactions between chloroaurate(III) complexes etc.

be ruled out.

$$
\mathrm{HNO}+\mathrm{NH}_{3} \mathrm{OH}^{+} \longrightarrow \mathrm{N}_{2}+2 \mathrm{H}_{2} \mathrm{O}+\mathrm{H}^{+}
$$

However, in both cases the reaction was found to be inhibited by $\mathrm{H}^{+}$ion.

The oxidation of $\mathrm{HNO}_{2}$ by $\left[\mathrm{AuCl}_{4}^{-}\right]^{19}$ in hydrochloric acid medium was first order with respect to $\left[\mathrm{Au}^{\mathrm{III}}\right]$ and $\left[\mathrm{HNO}_{2}\right] . \mathrm{H}^{+}$and $\mathrm{Cl}^{-}$ions inhibit the rate. The alkali metal ions have specific effects on the rate at constant ionic strength. The rate increases with increase in size of the alkali metal ion. The reaction appears to involve different gold(III) species, viz. $\mathrm{AuCl}_{4}{ }^{-}, \mathrm{AuCl}_{3}\left(\mathrm{OH}_{2}\right)$ and $\mathrm{AuCl}_{3}(\mathrm{OH})^{-}$.

These three species oxidize $\mathrm{HNO}_{2}$ in the following way,

$$
\begin{aligned}
& \mathrm{AuCl}_{4}^{-}+\mathrm{HNO}_{2}+\mathrm{H}_{2} \mathrm{O} \stackrel{k_{6}}{\longrightarrow} \\
& \mathrm{AuCl}_{2}^{-}+\mathrm{NO}_{3}^{-}+3 \mathrm{H}^{+}+2 \mathrm{Cl}^{-} \\
& \mathrm{AuCl}_{3}\left(\mathrm{OH}_{2}\right)+\mathrm{HNO}_{2} \stackrel{k_{7}}{\longrightarrow} \\
& \mathrm{AuCl}_{2}^{-}+\mathrm{NO}_{3}^{-}+3 \mathrm{H}^{+}+\mathrm{Cl}^{-} \\
& \mathrm{AuCl}_{3}(\mathrm{OH})^{-}+\mathrm{HNO}_{2} \stackrel{k_{8}}{\longrightarrow} \\
& \mathrm{AuCl}_{2}^{-}+\mathrm{NO}_{3}^{-}+2 \mathrm{H}^{+}+\mathrm{Cl}^{-}
\end{aligned}
$$

The following rate expression has been deduced

$$
\begin{aligned}
-d\left[\mathrm{Au}^{\mathrm{III}}\right] / d t= & \left(k_{6}+\frac{k_{7} K_{2}}{\left[\mathrm{Cl}^{-}\right]}+\frac{k_{8} K_{2} K_{3}}{\left[\mathrm{H}^{+}\right]\left[\mathrm{Cl}^{-}\right]}\right) \\
& {\left[\mathrm{HNO}_{2}\right]\left[\mathrm{Au}^{\mathrm{III}]}\right] }
\end{aligned}
$$

The electron transfer from nitrite to gold(III) may occur according to either of the following two Schemes 1 and 2.

$$
\begin{aligned}
& \mathrm{HNO}_{2}+\mathrm{Au}^{\mathrm{III}} \longrightarrow \mathrm{NO}_{2}^{-}+\mathrm{Au}^{\mathrm{II}}+\mathrm{H}^{+} \\
& \mathrm{NO}_{2}^{-}+\mathrm{Au}^{\mathrm{III}} \longrightarrow \mathrm{NO}_{2}^{+}+\mathrm{Au}^{\mathrm{II}} \\
& \mathrm{NO}_{2}^{+}+\mathrm{H}_{2} \mathrm{O} \longrightarrow \mathrm{NO}_{3}^{-}+2 \mathrm{H}^{+} \\
& 2 \mathrm{Au}^{\mathrm{II}} \longrightarrow \mathrm{Au}^{\mathrm{III}}+\mathrm{Au}^{\mathrm{I}} \cdot \\
& \quad \text { Scheme } 1 \\
& \mathrm{HNO}_{2}+\mathrm{Au}^{\mathrm{III}} \longrightarrow \mathrm{NO}_{2}^{+}+\mathrm{Au}^{\mathrm{I}}+\mathrm{H}^{+} \\
& \mathrm{NO}_{2}{ }^{+}+\mathrm{H}_{2} \mathrm{O} \longrightarrow \mathrm{NO}_{3}^{-}+2 \mathrm{H}^{+} \\
& \text {Scheme 2 }
\end{aligned}
$$

The reaction possibly occurs by a complementary mechanism via Scheme 2, although the other possibility cannot be totally ruled out simply on the basis of absence of polymerization of acrylamide in presence of the reaction mixture.
Copper(III) and silver(III) are known to oxidize sodium azide ${ }^{10,38}$ in alkaline medium through the intermediate formation of hexazene to give $\mathrm{N}_{2}$. An attempt was made to investigate the kinetics of oxidation of azide ion by chloroaurate(III) in acid medium. Gold(III) failed to oxidize azide ion. This may be due to the formation of stable compound between these two reactants as mentioned in the literature ${ }^{10}$.

Hypophosphite ion is oxidized by gold(III $)^{20}$ in aqueous hydrochloric acid to give phosphorous acid and $\mathrm{Au}^{\mathrm{I}}$. The reaction is first order in $\left[\mathrm{Au}^{\mathrm{III}}\right]$ and $\left[\mathrm{H}_{3} \mathrm{PO}_{2}\right]$. Hydrogen ion has no effect on the reaction rate in the acid range $(0.15-1.0) \mathrm{mol} \mathrm{dm}^{-3}$. The reaction takes place via one electron transfer process according to the following Scheme :
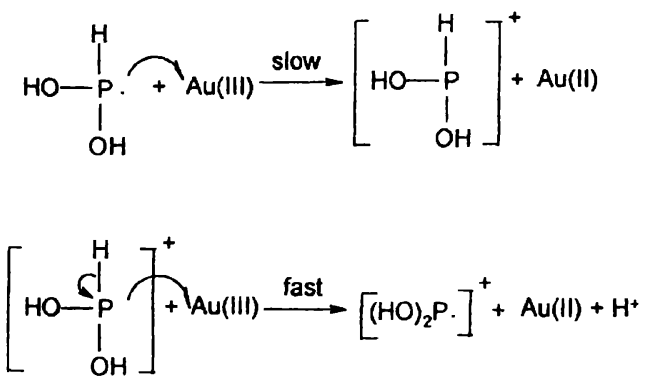

$$
\begin{aligned}
& {\left[(\mathrm{HO})_{2} \mathrm{P} \cdot\right]^{+}+\mathrm{H}_{2} \mathrm{O} \stackrel{\text { fast }}{\longrightarrow} \mathrm{H}_{3} \mathrm{PO}_{3}+\mathrm{H}^{+}} \\
& 2 \mathrm{Au}^{\mathrm{II}} \stackrel{\text { fast }}{\longrightarrow} \mathrm{Au}^{\mathrm{III}}+\mathrm{Au}^{\mathrm{I}}
\end{aligned}
$$

\section{Scheme 3}

The oxidation of arsenious acid by gold(III) ${ }^{21}$ in hydrochloric acid medium proceeds through the formation of a complex between arsenic(III) and gold(IIr) followed by its decomposition to give the products.

$$
\begin{aligned}
& \mathrm{As}^{\mathrm{III}}+\mathrm{Au}^{\mathrm{III}} \stackrel{K_{4}}{\rightleftharpoons}\left\{\mathrm{As}^{\mathrm{III}}, \mathrm{Au}^{\mathrm{III}}\right\} \\
& \left\{\mathrm{As}^{\mathrm{III}}, \mathrm{Au}^{\mathrm{III}}\right\} \stackrel{k_{9}}{\longrightarrow} \text { products }
\end{aligned}
$$

The rate expression has been suggested as

$$
-d\left[\mathrm{Au}^{\mathrm{III}}\right] / d t=\frac{k_{9} K_{4}\left[\mathrm{Au}^{\mathrm{III}}\right]\left[\mathrm{As}^{\mathrm{III}}\right]}{1+K_{4}\left[\mathrm{As}^{\mathrm{II}}\right]}
$$

$\mathrm{H}^{+}$ions have little effect on the reaction studied in the range (0.1-1.0) mol dm $\mathrm{dm}^{-3}$ of $\mathrm{HCl}$. A kinetic $\mathrm{Cl}^{-}$dependence would require additional chlorides in the activated 
complex. Since there is no $\mathrm{Cl}^{-}$dependence (at constant ionic strength) it can be explained by a bridge between the oxidant and arsenic(III). However, the pseudo-firstorder rate constant increases with an increase in salt concentration, which may be due to an increase in ionic strength or due to a variation in the nature, and concentration of the cations. It has been observed that the enhancement of the rate in presence of the cation is in the order : $\mathrm{K}^{+}>\mathrm{Na}^{+}>\mathrm{Li}^{+}$. The electron transfer from substrate to oxidant takes places as shown below.

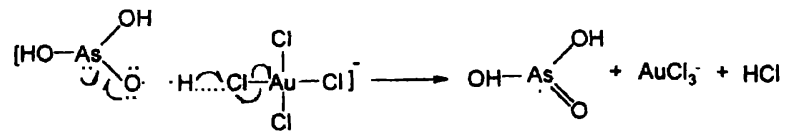

$\mathrm{OH}-\mathrm{As}_{\mathrm{O}}^{\mathrm{OH}}+\mathrm{AuCl}_{4}^{-}+\mathrm{H}_{2} \mathrm{O} \longrightarrow \mathrm{H}_{3} \mathrm{AsO}_{4}+\mathrm{AuCl}_{3}^{-}+\mathrm{HCl}$

$2 \mathrm{AuCl}_{3} \longrightarrow \mathrm{AuCl}_{4}+\mathrm{AuCl}_{2} \cdot$

Scheme 4

The decrease $(\sim 73 \%)$ in rate in presence of $12 \%(w /$ v) acrylamide solution corroborated the above non-complementary mechanisn.

Babshet and Gokavi ${ }^{22}$ reported the kinetics of oxidation of antimony(III) by gold(III) in (0.64-3.0) $\mathrm{mol} \mathrm{dm}^{-3}$ hydrochloric acid. The reaction involves the following equilibria (20-23) and the slow complementary two electron transfer between $\mathrm{AuCl}_{3}(\mathrm{OH})^{-}$and $\mathrm{SbCl}_{6}{ }^{3-}$ (24).

$$
\begin{aligned}
& \mathrm{HAuCl}_{4}+\mathrm{H}_{2} \mathrm{O} \rightleftharpoons K_{5} \rightleftharpoons \mathrm{AuCl}_{4}^{-}+\mathrm{H}_{3} \mathrm{O}^{+} \\
& \mathrm{AuCl}_{4}^{-}+2 \mathrm{H}_{2} \mathrm{O} \stackrel{K_{6}}{\rightleftharpoons} \mathrm{AuCl}_{3}(\mathrm{OH})^{-}+ \\
& \mathrm{H}_{3} \mathrm{O}^{+}+\mathrm{Cl}^{-} \\
& \mathrm{SbCl}_{4}^{-}+\mathrm{Cl}^{-} \stackrel{K_{7}}{\rightleftharpoons} \mathrm{SbCl}_{5}^{2-} \\
& \mathrm{SbCl}_{5}{ }^{2-}+\mathrm{Cl}^{-} \stackrel{K_{8}}{\rightleftharpoons} \mathrm{SbCl}_{6}{ }^{3-} \\
& \mathrm{AuCl}_{3}(\mathrm{OH})^{-}+\mathrm{SbCl}_{6}{ }^{3-} \stackrel{k_{10}}{\longrightarrow} \\
& \mathrm{AuCl}_{2}(\mathrm{OH})^{2-}+\mathrm{SbCl}_{6}{ }^{-}+\mathrm{Cl}^{-}
\end{aligned}
$$

The derived rate law is,

$$
-d\left[\mathrm{Au}^{\mathrm{III}}\right] / d t=\frac{k_{10} K_{5} K_{6} K_{7} K_{8}\left[\mathrm{Cl}^{-}\right]\left[\mathrm{Au}^{\mathrm{III}}\right]\left[\mathrm{Sb}^{\mathrm{III}}\right]}{\left[\mathrm{H}_{3} \mathrm{O}^{+}\right]\left(\left[\mathrm{H}_{3} \mathrm{O}^{+}\right]+K_{5}\right)}
$$

The observed orders with respect to $\left[\mathrm{H}^{+}\right]$and $\left[\mathrm{Cl}^{-}\right]$are -1.6 and 0.9 , respectively, which corroborate the above rate law. The effect of dielectric constant was observed by varying acetic acid ( 0 to $40 \% \mathrm{v} / \mathrm{v}$ ) and the rate was found to increase with increase in dielectric constant of the medium, which supported the reaction (eq. 24) between similarly charged ions. In majority of the reactions of gold(III), $\mathrm{Cl}^{-}$ions have either no effect (due to participation of $\mathrm{AuCl}_{4}^{-}$or $\mathrm{HAuCl}_{4}$ ) or a decelerating effect (due to participation of $\mathrm{AuCl}_{3}(\mathrm{OH})^{-}$and $\mathrm{AuCl}_{3}\left(\mathrm{H}_{2} \mathrm{O}\right)$ species). However, in the present study the reaction is accelerated by $\mathrm{Cl}^{-}$ions. The contradictory observation has been resolved by the involvement of the active species $\mathrm{SbCl}_{6}{ }^{3-}$, generated by the equilibria (22 and 23).

A number of mechanisms by which square planar system might oxidize a substrate, have been discussed in the literature $23,26,39$ with regard to gold(III) complexes. These include (i) attack by the reductant on a ligand (e.g. $\mathrm{Cl}^{-}$, $\mathrm{HO}^{-}$) with resulting atom transfer, (ii) nucleophilic attack on the metal ion with electron transfer occurring in a five-coordinate intermediate and (iii) electron transfer following ligand substitution. Annibale et al. ${ }^{23}$ found that the rates of oxidation of alkyl sulphides to sulfoxides by $\mathrm{AuCl}_{4}{ }^{-}$correlated directly with their basicity and inversely with steric hindrance in the alkyl chains.

The oxidation of sulphurous acid by gold(III) was studied $^{24}$ in the temperature range $292-310 \mathrm{~K}$ in (0.07-0.40) mol dm ${ }^{-3} \mathrm{HCl}$ medium keeping constant ionic strength by the addition of $\mathrm{NaCl}$. The influence of alkali metal chloride on the reaction rate was also studied and the rate constant was found to increase with increasing polarizability of the alkali metal ion at constant ionic strength. The reaction has been shown to occur through the intermediate formation of complex between the reactants followed by its decomposition to give free radical and gold(II). The free radical further reacts with another gold(III) to give sulphate ion and gold(II). Gold(II) reacts further with sulphurous acid and gives dithionate and gold(I).

$$
\begin{aligned}
& \mathrm{SO}_{2}(\mathrm{aq})+\mathrm{AuCl}_{4}^{-} \stackrel{K_{9}}{\rightleftharpoons} \text { Complex } \\
& \text { Complex } \stackrel{k_{11}}{\longrightarrow} \mathrm{HSO}_{3}^{\circ}+\mathrm{Au}^{\mathrm{II}}+\mathrm{H}^{+}
\end{aligned}
$$


Pal et al. : Electron transfer reactions between chloroaurate(III) complexes etc.

$$
\begin{aligned}
\mathrm{HSO}_{3}^{-}+\mathrm{Au}^{\mathrm{III}}+\mathrm{H}_{2} \mathrm{O} \stackrel{\text { fast }}{\longrightarrow} \\
\mathrm{SO}_{4}^{2-}+\mathrm{Au}^{\mathrm{II}}+3 \mathrm{H}^{+} \\
2 \mathrm{SO}_{2}(\mathrm{aq})+2 \mathrm{Au}^{\mathrm{II}}+2 \mathrm{H}_{2} \mathrm{O} \stackrel{\text { fast }}{\longrightarrow} \\
\mathrm{S}_{2} \mathrm{O}_{6}^{2-}+2 \mathrm{Au}^{\mathrm{I}}+4 \mathrm{H}^{+}
\end{aligned}
$$

The following rate expression has been deduced

$$
-d\left[\mathrm{Au}^{\mathrm{III}}\right] / d t=\frac{k_{11} K_{1} K_{9}\left[\mathrm{~S}^{\mathrm{IV}}\right]\left[\mathrm{HAuCl}_{4}\right]}{\left\{1+K_{9}\left[\mathrm{~S}^{\mathrm{IV}}\right]\right\}\left[\mathrm{H}^{+}\right]}
$$

where $K_{1}$ is the dissociation constant of $\mathrm{HAuCl}_{4}$ to give $\mathrm{H}^{+}$and $\mathrm{AuCl}_{4}^{-}$. Recently, Paclawski and Fitzner have studied $^{24(b)}$ the kinetics of oxidation of sodium bisulphite by $\mathrm{AuCl}_{4}{ }^{-}$in acid medium and observed similar type of one-electron transfer step with intermediate formation of free radicals.

The kinetics of the reaction between hydrogen peroxide and gold(III) ${ }^{25}$ in a hydrochloric acid medium (0.01$0.2 \mathrm{~mol} \mathrm{dm}^{-3}$ ) has been studied. From the known dissociation constant and protonation constant of $\mathrm{H}_{2} \mathrm{O}_{2}$, it has been shown that in this concentration range, hydrogen peroxide exists mainly as $\mathrm{H}_{2} \mathrm{O}_{2}$, both $\mathrm{HO}_{2}^{-}$and $\mathrm{H}_{3} \mathrm{O}_{2}{ }^{+}$ being insignificant. Thus in such a medium gold(III) oxidizes $\mathrm{H}_{2} \mathrm{O}_{2}$ through the intermediate formation of free radicals and the free radical $\left(\mathrm{HO}_{2}^{\circ}\right)$ reacts with gold(III) to give $\mathrm{O}_{2}$ as mentioned below.

$$
\begin{aligned}
& \mathrm{Au}^{\mathrm{III}}+\mathrm{H}_{2} \mathrm{O}_{2} \longrightarrow \mathrm{Au}^{\mathrm{II}}+\left(\mathrm{HO}_{2}^{\circ}\right)+\mathrm{H}^{+} \\
& \mathrm{Au}^{\mathrm{III}}+\left(\mathrm{HO}_{2}^{\circ}\right) \longrightarrow \mathrm{Au}^{\mathrm{II}}+\mathrm{HO}_{2}^{+} \\
& \mathrm{HO}_{2}{ }^{+} \longrightarrow \mathrm{H}^{+}+\mathrm{O}_{2}
\end{aligned}
$$

The reaction is first order with respect to [oxidant] as well as $\left[\mathrm{H}_{2} \mathrm{O}_{2}\right]$, but the reaction has an inverse dependence on $\left[\mathrm{H}^{+}\right]$and $\left[\mathrm{Cl}^{-}\right]$.

\section{Oxidation of organic compounds by gold(III) :}

The reduction of gold(III) by oxalate was studied by Maritz and van Eldik ${ }^{26}$ in the acidity range $0.0 \leq \mathrm{pH} \leq$ 3.5 and chloride concentration range $10^{-3} \leq\left[\mathrm{Cl}^{-}\right] \leq 0.8$ $M$ at $298 \mathrm{~K}$. Ionic strength of the reaction medium was kept constant $\left(1.0 \mathrm{~mol} \mathrm{dm}^{-3}\right)$ by adding $\mathrm{NaClO}_{4}$. Both $\mathrm{H}^{+}$and $\mathrm{Cl}^{-}$ions retard the rate of reaction as was observed in the aforementioned reactions of gold(III). Kinetic evidence indicated the participation of three gold(III) species (viz. $\mathrm{AuCl}_{4}^{-}, \mathrm{AuCl}_{3}\left(\mathrm{OH}_{2}\right)$ and $\mathrm{AuCl}_{3}(\mathrm{OH})^{-}$) as well as three different oxalate species (viz. $\mathrm{H}_{2} \mathrm{C}_{2} \mathrm{O}_{4}$, $\mathrm{HC}_{2} \mathrm{O}_{4}{ }^{-}$and $\mathrm{C}_{2} \mathrm{O}_{4}{ }^{2-}$ ). The reactivity of $\mathrm{AuCl}_{4}{ }^{-}$towards the substrate is much more $\mathrm{pH}$ dependent than that of $\mathrm{AuCl}_{3}(\mathrm{OH})^{-}$. The proposed mechanism consists of substitution reactions followed by electron transfer steps.
The observed products are $\mathrm{Au}^{\mathrm{I}}, \mathrm{Au}^{0}$, and $\mathrm{CO}_{2}$. Thę reductions of gold(III) by $\mathrm{HC}_{2} \mathrm{O}_{4}{ }^{-}$and $\mathrm{C}_{2} \mathrm{O}_{4}{ }^{2-}$ ions are much faster as compared to that by $\mathrm{H}_{2} \mathrm{C}_{2} \mathrm{O}_{4}$. The photolysis of the tetrachloroaurate(III) oxalate system has also been investigated by Maritz et al. ${ }^{40}$ at $\mathrm{pH} \leq 1.0$ spectrophotometrically as well as radiochemically. Kinetics of oxidation of substituted malonates by gold(III) in acidic solution have been reported ${ }^{41}$.

There were a number of investigations into the mechanism of substitution reactions of $\mathrm{AuCl}_{4}^{-}$with ethylene diamine $e^{42}$, diethylene triamine ${ }^{43}$, thiomorpholine-3-one ${ }^{44}$

Amino acids are basic component of protein molecules and play an important role in life processes. Reactions of amino acids with gold(III) will naturally be an important aspect for investigation from mechanistic view point. But no such kinetic investigation has been reported in the literature except the recent report of the $\mathrm{Au}^{\mathrm{III}}$-induced oxidation of isotopically labeled glycine by Zou et al. ${ }^{45}$. The reaction was studied at $\mathrm{pH} 2.4$ using $1 \mathrm{D}^{1} \mathrm{H}$ NMR and $2 \mathrm{D}\left[{ }^{1} \mathrm{H},{ }^{15} \mathrm{~N}\right]$ HSQC-TOCSY NMR spectroscopy. The proposed mechanism involves the initial formation of a coordination complex $\left[\mathrm{AuCl}_{3}(\mathrm{Gly}-\mathrm{N})\right]$ which gives rise to gold(I) and immine intermediate via two-electron transfer step. The immine undergoes fast hydrolysis to give glyoxylic acid and $\mathrm{NH}_{4}{ }^{+}$. The former gets further oxidized by gold(III) to produce formic acid, $\mathrm{CO}_{2}$, and gold(0). Such type of gold(III)-induced oxidation of glycine and related aminoacids may have some relation to the severe toxicity of gold drugs ${ }^{45}$.

Milgrom ${ }^{46(a)}$ has reported the oxidation of $2,3,7$, $8,12,13,17,18$-octaethyl porphyrin by gold(III) in pyridine, in which an ethyl substituent is oxidized to a chlorovinyl group. A typical 'rhodo-type' spectrum (450$650 \mathrm{~nm}$ ) typical of a porphyrin containing one electron withdrawing $\beta$-substituent, confirms the reaction product. The reactions of a few gold(III) complexes with serum albumin have been investigated ${ }^{46(b)}$ by the joint use of various spectroscopic methods and separation techniques. Both weak and strong metal-protein interactions have been observed. It is suggested that adduct formation for both of these gold(III) complexes occurs through coordination at the level of surface histidines.

The reactivity of a few alkanols and a number of aryl alcohols towards gold(III) have recently been studied ${ }^{27}$ in our laboratory in sodium acetate-acetic acid buffer medium in the $\mathrm{pH}$ range $3.72-4.80$. The reactions of aryl alcohols were studied in tert-butyl alcohol $(15 \% \mathrm{v} / \mathrm{v})$. The kinetic investigations reflect the involvement of all the three gold(III) species in the reactions. The observed 
kinetic isotopic effect indicates that the reactions occur via $\mathrm{C}-\mathrm{H}$ bond cleavage ${ }^{47}$, leading to the intermediate formation of free radicals and different gold(II) ${ }^{48-50}$ species. The formation of intermediate free radicals is supported by the observed polymeric suspension in the presence of acrylonitrile.

$$
\begin{gathered}
\mathrm{AuCl}_{4}^{-}+\mathrm{R}_{1} \mathrm{R}_{2} \mathrm{CHOH} \underset{\mathrm{R}_{1} \mathrm{R}_{2} \dot{\mathrm{COH}}+\mathrm{AuCl}_{4}^{2-}+\mathrm{H}^{+}}{\text {slow }} \\
\mathrm{AuCl}_{3}\left(\mathrm{OH}_{2}\right)+\mathrm{R}_{1} \mathrm{R}_{2} \mathrm{CHOH} \frac{k_{13}}{\text { slow }^{2}} \\
\mathrm{R}_{1} \mathrm{R}_{2} \dot{\mathrm{COH}}+\mathrm{AuCl}_{3}\left(\mathrm{OH}_{2}\right)^{-}+\mathrm{H}^{+} \\
\mathrm{AuCl}_{3}(\mathrm{OH})^{-}+\mathrm{R}_{1} \mathrm{R}_{2} \mathrm{CHOH} \underset{\mathrm{kHOW}_{14}}{\stackrel{\text { slow }^{2}}{\longrightarrow}} \\
\mathrm{R}_{1} \mathrm{R}_{2} \dot{\mathrm{COH}}+\mathrm{AuCl}_{3}(\mathrm{OH})^{2-}+\mathrm{H}^{+}
\end{gathered}
$$

The free radicals react further with the respective gold(III) species to give the carbonyl compounds and gold(II).

$$
\begin{aligned}
\mathrm{AuCl}_{4}{ }^{-}+\mathrm{R}_{1} \mathrm{R}_{2} \dot{\mathrm{COH}} \stackrel{\text { fast }}{\longrightarrow} \\
\mathrm{R}_{1} \mathrm{R}_{2} \mathrm{CO}+\mathrm{AuCl}_{4}{ }^{2-}+\mathrm{H}^{+} \\
\mathrm{AuCl}_{3}\left(\mathrm{OH}_{2}\right)+\mathrm{R}_{1} \mathrm{R}_{2} \dot{\mathrm{COH}} \stackrel{\text { fast }}{\longrightarrow} \\
\mathrm{R}_{1} \mathrm{R}_{2} \mathrm{CO}+\mathrm{AuCl}_{3}\left(\mathrm{OH}_{2}\right)^{-}+\mathrm{H}^{+} \\
\mathrm{AuCl}_{3}(\mathrm{OH})^{-}+\mathrm{R}_{1} \mathrm{R}_{2} \dot{\mathrm{COH}} \stackrel{\text { fast }}{\longrightarrow} \\
\mathrm{R}_{1} \mathrm{R}_{2} \mathrm{CO}+\mathrm{AuCl}_{3}(\mathrm{OH})^{2-}+\mathrm{H}^{+}
\end{aligned}
$$

$\mathrm{Au}^{\mathrm{II}}$ undergoes fast disproportionation into $\mathrm{Au}^{\mathrm{I}}$ and $\mathrm{Au}^{\mathrm{III}}$.

The reaction obeys the following rate expression :

$$
\begin{gathered}
-d\left[\mathrm{Au}^{\mathrm{III}}\right] / d t=\left\{k_{12}+\frac{\left(k_{13}-k_{12}\right) K_{2}}{\left[\mathrm{Cl}^{-}\right]}\right. \\
\left.+\frac{\left(k_{14}-k_{12}\right) K_{2} K_{3}}{\left[\mathrm{H}^{+}\right]\left[\mathrm{Cl}^{-}\right]}\right\}\left[\mathrm{R}_{1} \mathrm{R}_{2} \mathrm{CHOH}\right]\left[\mathrm{Au}^{\mathrm{III}}\right]
\end{gathered}
$$

The reactivity of alkanols towards gold(III) follows the order : ethanol $>$ methanol $>2$-propanol and that of substituted arylalcohols $\mathrm{NO}_{2}>\mathrm{H}>\mathrm{Cl}>\mathrm{OMe}$. The unsubstituted benzyl alcohol react at a faster rate than benzhydrol.

In the oxidation ${ }^{28}$ of some neutralized $\alpha$-hydroxy acids such as glycolic. lactic, $\alpha$-hydroxyisobutyric, mandelic, atrolactic and benzilic acids, gold(III) behaves as a two electron transfer oxidant. Spectrophotometric evidence in the initial stages of the reaction as well as the kinetic evidence indicate the formation of an intermediate cyclic complex, which decomposes in the rate determining step to give the respective reaction products, namely, formaldehyde, acetaldehyde, acetone. benzaldehyde. acetophenone and benzophenone. The observed kinetic isotopic effect suggests that the oxidation occurs via $\mathrm{C}-\mathrm{C}$ bond cleavage and not by $\mathrm{C}-\mathrm{H}$ bond breaking.

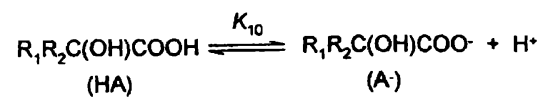

(A)

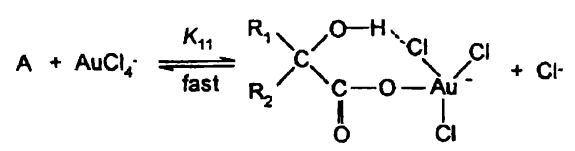

(x)

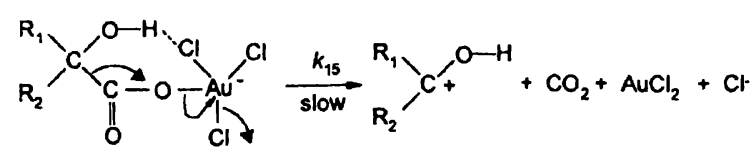

(X)

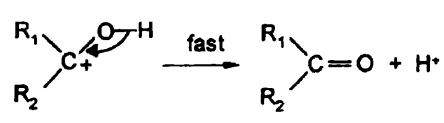

Scheme 5

The reaction mechanism shows that both $\mathrm{H}^{+}$and $\mathrm{Cl}^{-}$ ions inhibit the reaction rate, which is supported by the following rate expression.

$$
-d\left[\mathrm{Au}^{\mathrm{III}}\right] / d t=\frac{k_{15} K_{10} K_{11}[\mathrm{~S}]\left[\mathrm{Au}^{\mathrm{III}}\right]}{\left.\left\{K_{10}+\left[\mathrm{H}^{+}\right]\right\}[\mathrm{Cl}]^{-}\right]+K_{10} K_{11}[\mathrm{~S}]}(\mathrm{IX})
$$

The values of $K_{11}$ (equilibrium constant for the intermediate complex formation) and $k_{15}$ (disproportionation constant for the r.d.s.) are evaluated from the substrate effect, acid effect, and chloride effect and the values are found to corroborate with one another. The enthalpy of activation $\left(\Delta H^{H}\right)$ is found to be linearly related to the entropy of activation $\left(\Delta S^{\#}\right)$, which suggests that a similar type of mechanism is operative in all the reactions. The fairly large and negative $\Delta S^{\#}$ values further support the formation of the cyclic complex. The reactivity of the acids are in the order : glycolic $<$ lactic $<\alpha$-hydroxy isobutyric < benzilic < mandelic < atrolactic.

The reduction of gold(III) by glycolaldehyde in acetic acid-sodium acetate buffer medium has been studied ${ }^{29}$ in 
Pal et al. : Electron transfer reactions between chloroaurate(III) complexes etc.

the $\mathrm{pH}$ range 3.72-4.63. Glycolaldehyde, a dimer in the crystalline state, undergoes depolymerization, which is extremely fast in water and catalyzed by acid and base. All the different forms were detected by NMR spectra in $\mathrm{D}_{2} \mathrm{O}$, however, the monomeric form becomes predominant in very dilute solution $\left(<0.1 \mathrm{~mol} \mathrm{dm}^{-3}\right)$. The reaction is first-order with respect to $\left[\mathrm{Au}^{\mathrm{IIl}}\right]$ as well as [glycolaldehyde]. Both $\mathrm{H}^{+}$and $\mathrm{Cl}^{-}$ions retard the rate of reaction. Under the experimental conditions, $\mathrm{AuCl}_{4}{ }^{-}$, $\mathrm{AuCl}_{3}\left(\mathrm{OH}_{2}\right)$, and $\mathrm{AuCl}_{3}(\mathrm{OH})^{-}$oxidize the substrate to give glyoxal. Due to the presence of the electron withdrawing $-\mathrm{CH}_{2} \mathrm{OH}$ group, glycolaldehyde exists in the hydrated form. As a result the electron transfer takes place from the alcoholic oxygen to gold(III).

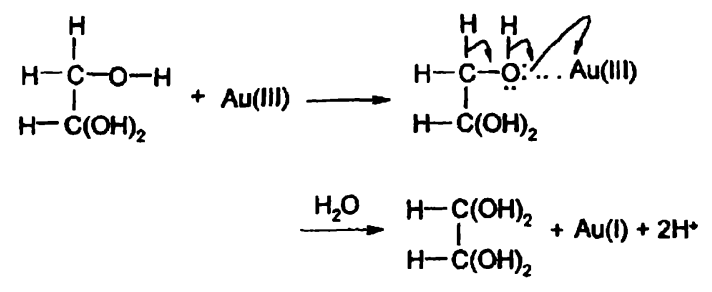

Scheme 6

In an alternative path, the enol form of the aldehyde reacts with gold(III), leading to the formation of glyoxal hydrate.

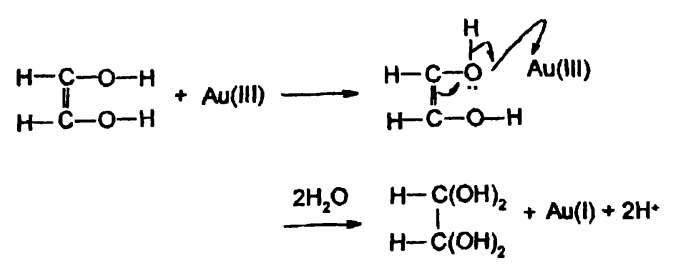

Scheme 7

Irrespective of whether aldehyde form or enol form of the substrate is oxidized by $\mathrm{Au}^{\mathrm{III}}$ to give glyoxal, the one step two-electron transfer rate determining process is corroborated by the absence of polymerization in the presence of vinyl compound.

Carbohydrates have unique biological activity, which serve as store and source of energy ${ }^{51}$. Of the different carbohydrates, the monosaccharides are of vast biological importance, as they are known to be involved in carbohydrate metabolism ${ }^{52}$. They are reported to exist in acyclic and cyclic forms and possess a higher density of functional groups than any other class of organic compounds ${ }^{53}$. The mechanisms of the oxidation reactions in- volving monosaccharıdes are of immense importance.

The reactivity of some aldoses towards gold(III) was studied in $\mathrm{HCl}$ medium ${ }^{54.55}$, where $\mathrm{AuCl}_{4}^{-}$was the only active species of gold(III). Very recently the same reactions have been studied more elaborately in sodium acetate-acetic acid buffer medium ${ }^{30}$. In the latter studies, all the three different gold(III) species are involved and both $\mathrm{H}^{+}$and $\mathrm{Cl}^{-}$ions retard the reaction rate. Under the kinetic conditions, reaction appears to involve the intermediate formation of free radicals and $\mathrm{Au}^{\mathrm{II}}$. Aldoses react with gold(III) in the order : triose $>$ tetrose $>$ pentose $>$ hexose. The plots of $\log k_{\text {obs }}$ versus ' $n$ ' (where $n=$ number of asymmetric center) is linear (Fig 1)

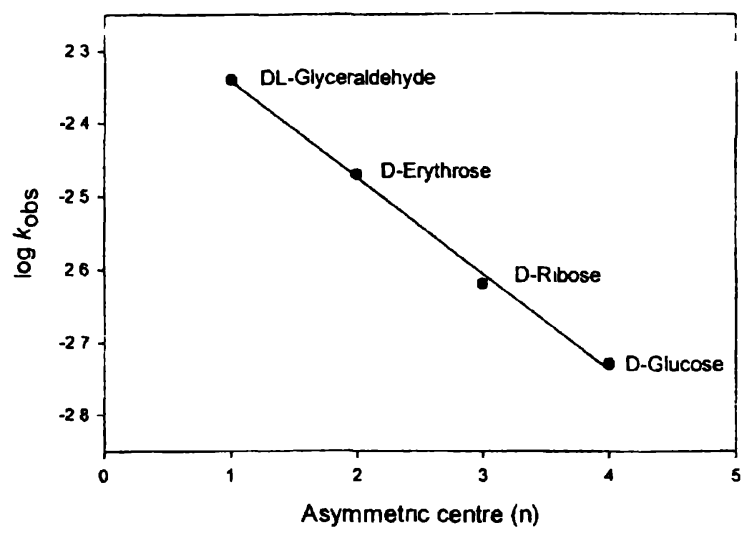

Fig. 1. Dependence of the reaction rate of the oxidation of some aldoses by gold(III) on their number of asymmetric centers (n) Plot of $\log k_{\mathrm{obs}}$ versus ' $n$ '

Aldohexoses exist mainly in the pyranoid form, where as aldopentoses exist in equilibrium in both pyranoid and furanoid forms. On the other hand, triose and tetrose exist mostly in the hydrated acyclic forms. The reactions occur as shown in Schemes 8-10.

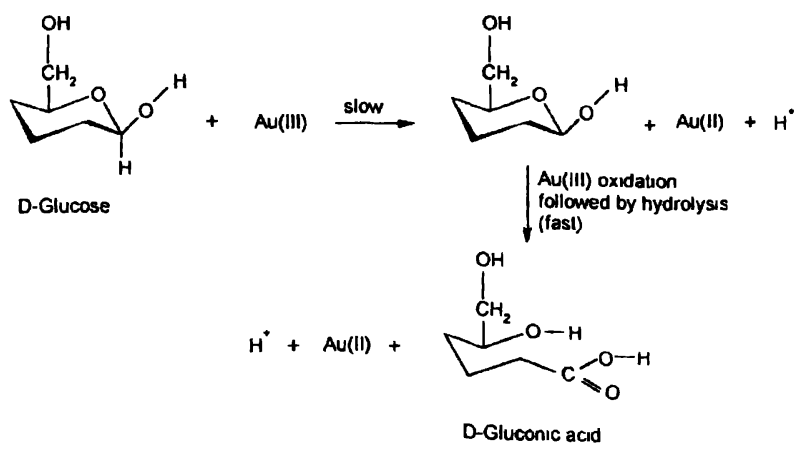

Scheme 8 


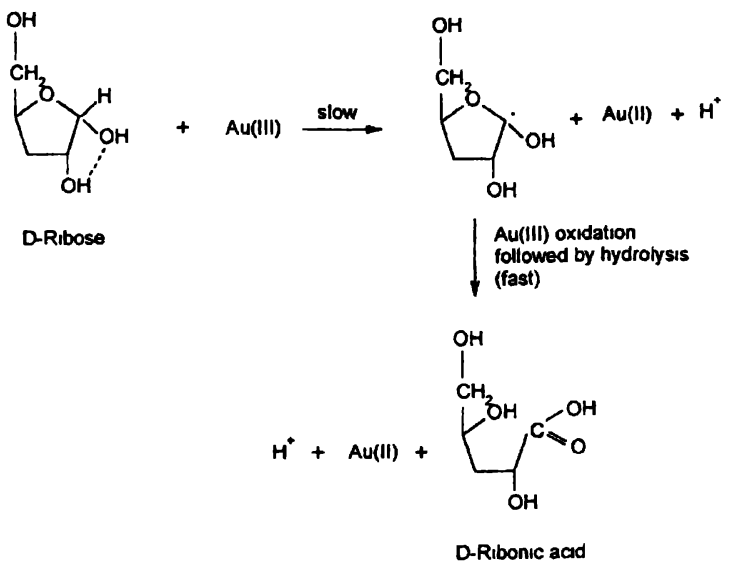

Scheme 9
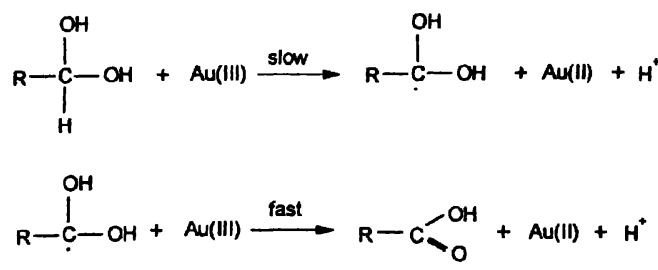

$\mathrm{R}=-(\mathrm{CHOH})_{2} \mathrm{CH}_{2} \mathrm{O}$ for D-erythrose

$\mathrm{R}=\mathrm{CHOHCH}_{2} \mathrm{O}$ for $\mathrm{DL}$-glyceraldehyde

Scheme 10

\section{Discussion}

The salient features of the oxidations by gold(III) are as follows :

Increase in $\left[\mathrm{H}^{+}\right]$decreases the rate of reactions. At higher acid concentrations of $\left[\mathrm{H}^{+}\right] \geq 0.5 \mathrm{~mol} \mathrm{dm}^{-3}$, $\mathrm{AuCl}_{4}{ }^{-}$or $\mathrm{HAuCl}_{4}$ is the reactive gold(III) species whereas in much lower acidities of $[\mathrm{HCl}] \ll 0.5 \mathrm{~mol} \mathrm{dm}^{-3}$, or, in sodium acetate-acetic acid buffer medium, $\mathrm{AuCl}_{4}{ }^{-}$, $\mathrm{AuCl}_{3}\left(\mathrm{OH}_{2}\right)$ and $\mathrm{AuCl}_{3}(\mathrm{OH})^{-}$are the reactive species which oxidize the substrates.

$\mathrm{Cl}^{-}$retards the rate of the reactions. This is due to the fact that it lowers the concentrations of $\mathrm{AuCl}_{3}\left(\mathrm{OH}_{2}\right)$ and $\mathrm{AuCl}_{3}(\mathrm{OH})^{-}$. Of these three species $\mathrm{AuCl}_{3}(\mathrm{OH})^{-}$is the most reactive one. Thus the reactivity of gold(III) species follow the order, $\mathrm{AuCl}_{3}(\mathrm{OH})^{-}>\mathrm{AuCl}_{3}\left(\mathrm{OH}_{2}\right)>\mathrm{AuCl}_{4}^{-}$. The greater reactivity of $\mathrm{AuCl}_{3}(\mathrm{OH})^{-}$and $\mathrm{AuCl}_{3}\left(\mathrm{OH}_{2}\right)$ over $\mathrm{AuCl}_{4}{ }^{-}$may be ascribed to the easier displacement of an $\mathrm{OH}^{-} / \mathrm{OH}_{2}$ group than a $\mathrm{Cl}^{-}$ion ${ }^{26}$.

Influence of ionic strength was noticeable in the oxidation of some inorganic ${ }^{19,21,24}$ and organic ${ }^{28}$ compounds by gold(III). The rates in the presence of different salts like $\mathrm{NaCl}, \mathrm{NaClO}_{4}$ and $\mathrm{Na}_{2} \mathrm{SO}_{4}$ at constant ionic strength $\left(0.1 \mathrm{~mol} \mathrm{dm}^{-3}\right)$ was found to be same in the oxidation of inorganic compounds indicating that anions do not have any influence on the reaction rate. On the other hand, the rates were found to depend not only on the ionic strength but also on the concentration and nature of the cations. The rates increase as the ionic strength increases. The reactions take place between an ion and a neutral species or between two different ionic species depending upon the substrates, which were used.

It has been suggested that alkali metal ions serve as an electron bridge and that a linear relationship exists between the experimental rate constants and polarizability of the cations. An attempt was also made to correlate rate constants with crystal radii $(\AA)$, hydration energy $(\mathrm{kJ}$ $\left.\mathrm{mol}^{-1}\right)$, polarizability $\left(\mathrm{cm}^{-3}\right)$ and ionic potential $(\mathrm{kJ}$ $\mathrm{mol}^{-1}$ ) of the alkali metal ions 21,24 . Although the plots of $k_{\text {obs }}$ (at [salt] $=0.1 \mathrm{~mol} \mathrm{dm}^{-3}$ ) versus different physical properties are not linear except for the polarizability, the pseudo-first-order rate constant increases in the order : $\mathrm{Li}^{+}<\mathrm{Na}^{+}<\mathrm{K}^{+}<\mathrm{Rb}^{+}<\mathrm{Cs}^{+}$. Thus, the variation of rate constant in the presence of different cations has been ascribed to the ion association between $\mathrm{M}^{+}$and either of the anionic gold(III) species. The ion association is higher for small alkali metal ions, thereby decreasing the ionic strength and hence the rate constant.

The oxidation of inorganic and organic reductants by gold(III) may take place by either one electron or one step two-electron transfer process. It will be interesting to compare the activation parameters of different redox processes involving gold(III). The rate constants for the oxidation of $\mathrm{Pt}^{\mathrm{II}}{ }^{16}, \mathrm{Fe}^{\mathrm{II}}{ }^{16}, \mathrm{Tl}^{\mathrm{I}}{ }^{37}$ and $\mathrm{Pt}(\mathrm{CN})_{4}{ }^{2-36}$ by gold(III) have been studied under different experimental conditions but at constant temperature of $298 \mathrm{~K}$. On the other hand, several other reactions have been studied at different temperatures and their activation parameters have been evaluated.

The oxidations of the inorganic reductants like $\mathrm{N}_{2} \mathrm{H}_{5}{ }^{+}$, $\mathrm{NH}_{3} \mathrm{OH}^{+}, \mathrm{H}_{3} \mathrm{PO}_{2}, \mathrm{H}_{3} \mathrm{AsO}_{2}, \mathrm{H}_{2} \mathrm{SO}_{3}$ and $\mathrm{H}_{2} \mathrm{O}_{2}$ have been shown to occur through the intermediate formation of free radicals and gold(II). This was based on the determination of stoichiometry in excess substrates, polymerization reaction and experimentally obtained activation parameters. The reactions are characterized by activation enthalpy in the region (27-78) $\mathrm{kJ} \mathrm{mol}^{-1}$ except in the oxidation of $\mathrm{H}_{3} \mathrm{PO}_{2}$ by gold(III) where the value is $128 \mathrm{~kJ}$ $\mathrm{mol}^{-1}$. Thus much higher value obtained is possibly because one electron from the lone pair of the active form 
Pal et al. : Electron transfer reactions between chloroaurate(III) complexes etc

Table 1. The values of second-order-rate constants $\left(k_{2}=k_{\mathrm{obs}} /[S]\right)$, equilibrium constant $(K)$ for the fast step, disproportionation constants $(k)$ for the slow step and the related thermodynamic parameters for the oxıdation of some inorganic compounds by gold(III) ${ }^{a}$

\begin{tabular}{|c|c|c|c|c|c|c|}
\hline Substrate & $\begin{array}{l}{\left[\mathrm{H}^{+}\right]=\left[\mathrm{Cl}^{-}\right] /} \\
\mathrm{mol} \mathrm{dm}\end{array}$ & $\begin{array}{l}10^{2} k_{2} / \\
\mathrm{dm}^{3} \mathrm{~mol}^{-1} \mathrm{~s}^{-1}\end{array}$ & $\begin{array}{l}10^{2} \mathrm{k} \mathrm{dm}^{3} \mathrm{~mol}^{-1} \mathrm{~s}^{-1} \\
(K)\end{array}$ & $\begin{array}{l}\Delta H^{0} / \mathrm{kJ} \mathrm{mol}^{-1} \\
\left(\Delta S^{0} / \mathrm{JK}^{-1} \mathrm{~mol}^{-1}\right)\end{array}$ & $\begin{array}{l}\Delta H^{H} / \mathrm{kJ} \mathrm{mol}{ }^{-1} \\
\left(\Delta S^{H} / \mathrm{JK}^{-1} \mathrm{~mol}^{-1}\right)\end{array}$ & Ret \\
\hline $\mathrm{N}_{2} \mathrm{H}_{5}^{+}$ & 10 & $176 \pm 90$ & - & - & $\begin{array}{l}53 \pm 24 \\
(61 \pm 3)\end{array}$ & 17 \\
\hline $\mathrm{NH}_{3} \mathrm{OH}^{+}$ & 0.50 & $0085 \pm 0002$ & - & - & $\begin{array}{l}78 \pm 21 \\
(59 \pm 3)\end{array}$ & $18(a)$ \\
\hline $\mathrm{HNO}_{2}$ & 002 & $476 \pm 011$ & - & - & $\begin{array}{l}55 \pm 2 \\
(-86 \pm 7)\end{array}$ & 19 \\
\hline $\mathrm{H}_{3} \mathrm{PO}_{2}^{b}$ & 10 & $137 \pm 02$ & - & - & $\begin{array}{l}128 \pm 2 \\
(136 \pm 6)\end{array}$ & 20 \\
\hline $\mathrm{HAsO}_{2}$ & 10 & - & $\begin{array}{l}0139 \pm 002 \\
(242 \pm 12)\end{array}$ & $\begin{array}{l}-675 \pm 1 \\
(414 \pm 082)\end{array}$ & $\begin{array}{l}49 \pm 2 \\
(-137 \pm 5)\end{array}$ & 21 \\
\hline $\mathrm{SbCl}_{3}$ & 30 & $90 \pm 4$ & - & - & $\begin{array}{l}19 \pm 1 \\
(-182 \pm 4)\end{array}$ & 22 \\
\hline $\mathrm{TlCl}_{2}^{-c}$ & 30 & $300 \pm 10$ & - & - & - & 37 \\
\hline $\mathrm{H}_{2} \mathrm{SO}_{3}{ }^{d}$ & 04 & - & $\begin{array}{l}0358 \pm 004 \\
(4891 \pm 11)\end{array}$ & $\begin{array}{l}-182 \pm 05 \\
(118 \pm 04)\end{array}$ & $\begin{array}{l}27 \pm 25 \\
(-203 \pm 10)\end{array}$ & 24 \\
\hline $\mathrm{H}_{2} \mathrm{O}_{2}$ & 002 & $0139 \pm 003$ & - & - & $\begin{array}{l}55 \pm 2 \\
(-137 \pm 7)\end{array}$ & 25 \\
\hline
\end{tabular}

${ }^{a_{T}}$ The reactions were performed in $\mathrm{HCl}$ medium The values of $k_{2}, k$ and $K$ were obtained at $303 \mathrm{~K}$ unless stated otherwise The errors correspond to two least-squares standard deviations $( \pm 2 \sigma) .{ }^{b}$ At $308 \mathrm{~K}{ }^{c}$ At $298 \mathrm{~K}{ }^{d}$ At $304 \mathrm{~K}$

of the $\mathrm{H}_{3} \mathrm{PO}_{2}$ is transferred to gold(III) and not by $\mathrm{P}-\mathrm{H}$ bond fission. The oxidation of $\mathrm{SbCl}_{3}$ by gold(III), which has been studied ${ }^{28}$ in $\mathrm{HCl}$ medium, has been shown to occur not through the intermediate formation of $\mathrm{Sb}^{\mathrm{IV}}$ but by one step two electron transfer process to give $\mathrm{Sb}^{\mathrm{V}}$. The much lower activation enthalpy of $19.2 \mathrm{~kJ} \mathrm{~mol}^{-1}$ as compared to those mentioned above corroborates the above contention. No attempt has been made to correlate $\Delta S^{\#}$ with $\Delta H^{\#}$ since oxidations of inorganic substrates were carried out under different experimental conditions and the reactions occur via different mechanisms. Kinetic results and thermodynamic parameters for different inorganic compounds are presented in Table 1.

The oxidation of alcohols and aldoses by gold(III) occurs via $\mathrm{C}-\mathrm{H}$ bond cleavage whereas $\alpha$-hydroxy acids are oxidized via $\mathrm{C}-\mathrm{C}$ bond cleavage. The kinetic results and activation parameters of these two series of reactions are recorded in Table 2 . The activation enthalpy is found to depend on the acid dissociation constants of $\alpha$-hydroxy acids. The $\mathrm{p} K_{\mathrm{a}}$ values $^{56}$ of some $\alpha$-hydroxy acids at 298 $\mathrm{K}$ are known, the values are $3.83,3.86,3.65,3.41$, and 3.04 for glycolic, lactic, $\alpha$-hydroxy isobutyric acid, mandelic and benzilic acids, respectively. The plot of $\Delta H^{\#}$ against $\mathrm{p} K_{\mathrm{n}}$ is linear ${ }^{56}$ (Fig. 2). Again two different lin- ear plots of $\Delta S^{\#}$ against $\Delta H^{\#}$ are obtained in these two series of reactions (Fig. 3). The results indicate that $\alpha$ hydroxy acid oxidations are characterized by lower activation parameters than the alcohols and aldoses. In an oxidation-reduction between an ion of a transition element and a compound or ion derived from non transition

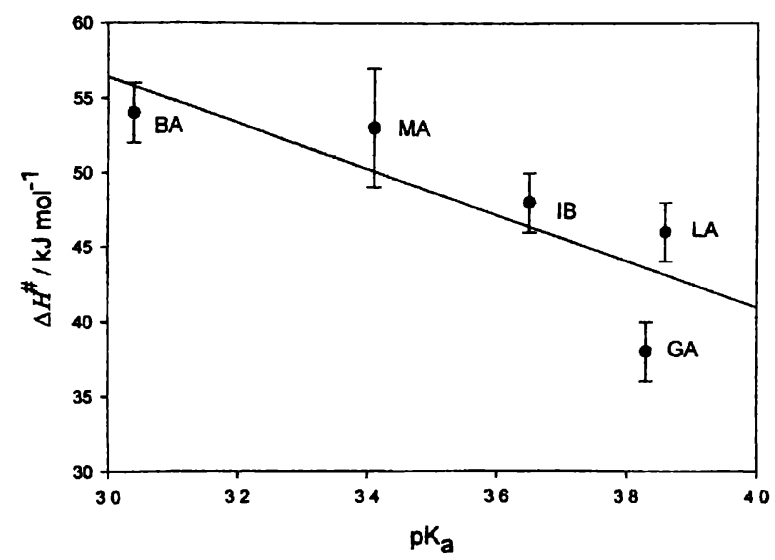

Fig. 2. The dependence of $\Delta H^{\#}$ on $\mathrm{p} K_{\mathrm{a}}$ of $\alpha$-hydroxy acids for ox1dation with gold(III) GA = glycolic acid, LA = lactic acid, $\mathrm{IB}=\alpha$-hydroxy isobutyric acıd, MA $=$ mandelic acıd and $\mathrm{BA}=$ benzilic acid 


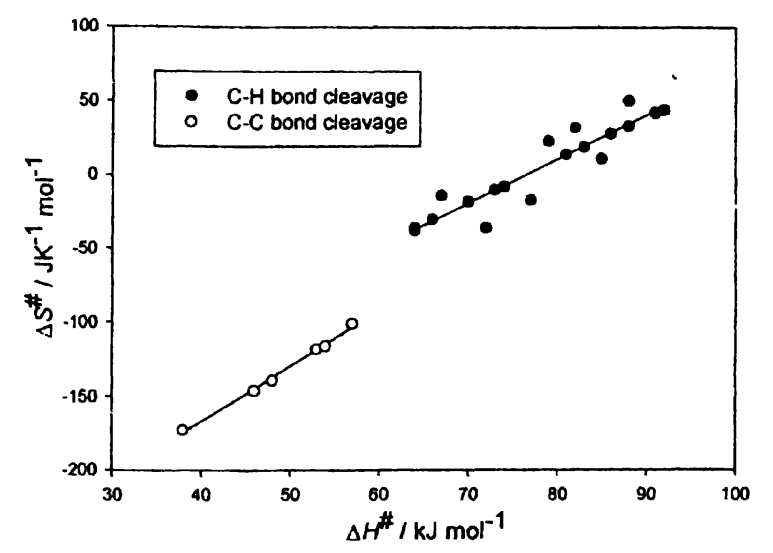

Fig. 3. Isokinetic correlation for the oxidation of some organic compounds by gold(III) showing $\mathrm{C}-\mathrm{H}$ bond cleavage (alcohols and aldoses) and $\mathrm{C}-\mathrm{C}$ bond cleavage ( $\alpha$-hydroxy acids) mechanism in $\mathrm{CH}_{3} \mathrm{COOH}-\mathrm{CH}_{3} \mathrm{COONa}$ buffer medium. Plot of $\Delta S^{\sharp}$ versus $\Delta H^{H}$.

element, the formation of free radical intermediate from a second reactant by 1-equivalent reaction is likely in some cases to be more endothermic process than the corresponding 2-equivalent reaction ${ }^{57}$. The exothermic process is able to lower the activation enthalpy of the one step two equivalent reaction below that of the corresponding one-electron process ${ }^{58-60}$. The enthalpies as well as entropies of activation for a two electron transfer process are smaller than those obtained in the studies where gold(III) behaves as one electron transfer oxidant. The smaller activation enthalpies obtained in the oxidations of $\alpha$-hydroxy acids lend further support to the fact that gold(III) behaves as a two-electron transfer oxidant in this series of reactions.

A few apparent gold(II) complexes are reported ${ }^{61}$ to be mixture of gold(I)-gold(III) oxidation states. Again, the formation of unstable gold(II) as an intermediate has also been predicted by a number of workers. However, it has been possible to stabilize this unstable oxidation state in some cases ${ }^{62-67}$. In one case gold(II) is stabilized by the presence of a strong $\mathrm{Au}-\mathrm{Au}$ bond in certain dimeric complexes and these complexes are diamagnetic ${ }^{3}$. In other cases paramagnetic gold(II) complexes are reported to be stabilized by the delocalisation of the unpaired electron over the ligands. The synthesis and characterization of paramagnetic gold(II) complexes with the ligands $O$ aminobenzenethiol (Habt), $O$-methylthioaniline (Hmta), 1,2-di(aminophenylthio)ethane (dae) and $N$-(2-pyridyl methyl)-2-mercaptoaniline (Hpma) have been reported. These complexes are found to be extremely stable in solid state and reasonably stable in solution. The nature and structure of the compounds were obtained from the analysis of their EPR spectra ${ }^{3}$. Thus convincing evidences in favour of the formation of intermediate transition state of gold(II) as well as stable gold(II) complexes are available in the literature as mentioned above.

Gold trichloride is dimeric in both solid and gaseous state $^{68}$ whereas tetrachloroaurate(III) ion exists as square planar configuration. The reducing substrates enter into the coordination sphere of planar gold(III) complex and forms an unstable intermediate transition state or complex which then undergoes electron transfer to give the products. The question of whether the reactions proceed by an outer- or inner-sphere mechanism and whether the coordination sphere of the intermediate state of gold remains intact or not cannot be answered at this stage. However, the reaction rate is much slower compared to those reactions, which occur by typical outer sphere mechanism ${ }^{69,70}$. It is unlikely that $\mathrm{AuCl}_{4}{ }^{-}$is reduced to $\mathrm{AuCl}_{4}{ }^{3-}$, rather planar $\mathrm{AuCl}_{4}{ }^{-}$is reduced to $\mathrm{AuCl}_{2}{ }^{-}$. Again, $\mathrm{FeCl}_{2}{ }^{16}$, $\mathrm{PtCl}_{4}{ }^{2-16}, \mathrm{TlCl}^{37}$ and $\mathrm{SbCl}_{3}{ }^{22}$ have been shown to be oxidized by $\mathrm{AuCl}_{4}^{-}$to give $\mathrm{AuCl}_{2}^{-}$. It is to be mentioned further that oxidation of $\mathrm{Pt}(\mathrm{CN})_{4}{ }^{2-}$ by $\mathrm{AuCl}_{4}{ }^{-}$, $\mathrm{AuCl}_{3}\left(\mathrm{H}_{2} \mathrm{O}\right)$ and $\mathrm{AuCl}_{3}(\mathrm{OH})^{-}$have also been shown to occur via chloride bridged inner-sphere mechanism. Thus gold(I) which is formed is reduced to gold metal in excess reductant or by disproportionation of the gold(I) when the reaction mixture was allowed to stand for several hours. However, no detectable amount of gold metal was formed under reaction conditions used during kinetic measurements.

1 : 10-Phenanthroline as well as $2,2^{\prime}$-bipyridyl complexes of gold(III $)^{5(b), 5(c)}$ have been prepared and isolated in their solid states. Since there is no data to investigate the reactivities of the inorganic and organic reducing substrates towards cationic complexes of gold(III), it may be interesting to investigate such reactions in future. It is known ${ }^{71}$ that collision between like charged ions are less likely whereas between two unlike charges more likely. This is because a negative ion will find itself close to a positive ion rather than to another negative ion. As a result in the reactions between ions of unlike sign there is generally an entropy increase going from reactants to activated complex whereas for ions of like sign there is generally an entropy decrease. Such studies, therefore. using cationic complexes of gold(III) may provide a clear picture in understanding the mechanisms of reactions involving cationic as well as anionic gold(III) complexes. 
Pal et al. : Electron transfer reactions between chloroaurate(III) complexes etc.

Table 2. The values of second-order-rate constants $\left(k_{2}=k_{\text {obs }} /[S]\right)$, equilibrium constant $(K)$ for the fast step, disproportionation constants $(k)$ for the slow step (at $298 \mathrm{~K}$ ) and the related thermodynamic parameters for the oxidation of some organic compounds by gold(III)

\begin{tabular}{|c|c|c|c|}
\hline Substrate & $\begin{array}{c}10^{2} k_{2} / \mathrm{dm}^{3} \mathrm{~mol}^{-1} \mathrm{~s}^{-1} \\
\text { or } * 10^{2} \mathrm{k} / \mathrm{s}^{-1}\left(10^{2} \mathrm{~K}\right)\end{array}$ & $\Delta H^{0} / \mathrm{kJ} \mathrm{mol}^{-1}\left(\Delta S^{0} / \mathrm{JK}^{-1} \mathrm{~mol}^{-1}\right)$ & $\Delta H^{\# /} / \mathrm{kJ} \mathrm{mol}^{-1}\left(\Delta S^{\# /} / \mathrm{JK}^{-1} \mathrm{~mol}^{-1}\right)$ \\
\hline Methanol & $2.56 \pm 0.08$ & - & $77 \pm 2(-17 \pm 7)$ \\
\hline Ethanol & $3.36 \pm 0.04$ & - & $85 \pm 2(11 \pm 7)$ \\
\hline Isopropanol & $1.85 \pm 0.04$ & - & $72 \pm 2(-36 \pm 14)$ \\
\hline Benzyl alcohol (BA) & $30.4 \pm 0.24$ & - & $73 \pm 2(-10 \pm 7)$ \\
\hline$O$-Nitro BA & $36.7 \pm 0.16$ & - & $70 \pm 4(-18 \pm 14)$ \\
\hline$m$-Nitro BA & $42.8 \pm 0.32$ & - & $66 \pm 6(-30 \pm 7)$ \\
\hline p-Nitro BA & $49.2 \pm 0.80$ & - & $64 \pm 2(-36 \pm 7)$ \\
\hline o-Chloro BA & $12.8 \pm 080$ & - & $88 \pm 2(33 \pm 7)$ \\
\hline m-Chloro BA & $17.1 \pm 0.20$ & - & $83 \pm 8(19 \pm 27)$ \\
\hline p-Chloro BA & $25.8 \pm 0.40$ & - & $74 \pm 4(-8 \pm 14)$ \\
\hline o-Methoxy BA & $10.9 \pm 0.80$ & - & $91 \pm 2(42 \pm 7)$ \\
\hline$m$-Methoxy BA & $14.8 \pm 0.20$ & - & $86 \pm 2(28 \pm 7)$ \\
\hline p-Methoxy BA & $22.1 \pm 0.28$ & - & $81 \pm 2(14 \pm 7)$ \\
\hline Benzhydrol & $9.56 \pm 0.80$ & - & $92 \pm 4(44 \pm 14)$ \\
\hline D-Glucose & $94.0 \pm 3.00$ & - & $88 \pm 2(50 \pm 7)$ \\
\hline D-Ribose & $120 \pm 4.00$ & - & $82 \pm 2(32 \pm 7)$ \\
\hline D-Erythrose & $168 \pm 5.00$ & - & $79 \pm 3(23 \pm 10)$ \\
\hline DL-Glyceraldehyde & $228 \pm 10.0$ & - & $67 \pm 6(-14 \pm 20)$ \\
\hline Glycolaldehyde & $42.7 \pm 0.06$ & - & $64 \pm 4(-38 \pm 12)$ \\
\hline Glycolic acid & $* 0.113 \pm 0.007(5.75 \pm 0.14)$ & $20 \pm 4(45 \pm 13)$ & $38 \pm 2(-173 \pm 7)$ \\
\hline Lactic acid & $* 0.119 \pm 0.005(7.43 \pm 0.17)$ & $9 \pm 4(8 \pm 13)$ & $46 \pm 2(-146 \pm 7)$ \\
\hline $\begin{array}{l}\alpha \text {-Hydroxy } \\
\text { isobutyric acid }\end{array}$ & $* 0.131 \pm 0.005(6.19 \pm 0.1)$ & $25 \pm 4(59 \pm 13)$ & $48 \pm 2(-139 \pm 7)$ \\
\hline Mandelic acid & $* 0.233 \pm 0.03(3.09 \pm 0.1)$ & $11 \pm 4(9 \pm 13)$ & $53 \pm 4(-118 \pm 14)$ \\
\hline Atrolactic acid & $* 0.239 \pm 0.02$ & - & $57 \pm 2(-101 \pm 7)$ \\
\hline Benzilic acid & $* 0.158 \pm 0.01(3.97 \pm 0.13)$ & $13 \pm 4(19 \pm 13)$ & $54 \pm 2(-116 \pm 7)$ \\
\hline
\end{tabular}

The $\mathrm{pH}$ of the reactions in acetate buffer were 4.05 for alcohols, glycolaldehyde and $\alpha$-hydroxy acids reactions and for aldoses $\mathrm{pH}=3.72$. $\left[\mathrm{Cl}^{-}\right]$were $0.01,0.002,0.01$ and $0.03 \mathrm{~mol} \mathrm{dm}^{-3}$ for the reactions of alcohols, aldoses, glycolaldehyde, $\alpha$-hydroxy acids, respectively.

\section{Experimental}

The absorption spectrum of $\mathrm{AuCl}_{4}{ }^{-}$obtained from different sources and under different experimental conditions are different. Gangopadhyay and Chakraborty ${ }^{72}$ prepared tetrachloro complex by decomposing bromocomplex with aqua regia and reported that tetrachloro complex shows two intense bands in the ultraviolet region. These were interpreted as charge transfer bands, the transfer is from halogen $p$ to gold $d$ orbital. It may be mentioned that they have recorded the spectrum in $1 \mathrm{~cm}$ silica cell in Beckman DU model spectrophotometer. Spectra of $\mathrm{AuCl}_{4}{ }^{-}$ were also recorded for different $\left[\mathrm{Cl}^{-}\right](0.001-1.0) \mathrm{mol}$ $\mathrm{dm}^{-3}$ at various acidities ${ }^{26}$. The spectrum for $1.0 \mathrm{~mol}$ $\mathrm{dm}^{-3}\left[\mathrm{Cl}^{-}\right]$and $\mathrm{pH} 2.0$ was found to be the same as that obtained for $1.0 \mathrm{~mol} \mathrm{dm}{ }^{-3} \mathrm{HCl}^{26}$. An absorption maxi- mum at $313 \mathrm{~nm}\left(\varepsilon=4.86 \times 10^{3} \mathrm{~mol}^{-1} \mathrm{dm}^{3} \mathrm{~cm}^{-1}\right)$ was obtained $^{26}$ with isosbestic point at $296 \mathrm{~nm}$. Moreover, the absorption spectra of gold(III) solutions in the concentration range $(0.30-2.37) \times 10^{-4} \mathrm{~mol} \mathrm{dm}^{-3}$ in $0.01 \mathrm{~mol}$ $\mathrm{dm}^{-3}$ hydrochloric acid were studied in our laboratory in the UV region on a Shimadzu 1700 model UV-VIS spectrophotometer (Fig. 4) and the spectral pattern was found to remain unaltered with changes in the concentration of gold(III). An absorption maximum at $313 \mathrm{~nm}$ and a minimum of $270 \mathrm{~nm}$ were in good agreement with the literature value ${ }^{26}$. Beer's law has been found to be valid in the concentration range studied. The addition of acid $(0.01-$ $1.0 \mathrm{~mol} \mathrm{dm}^{-3}$ ) does not seem to have any change in the absorption spectrum at constant $\left[\mathrm{Cl}^{-}\right]$. 


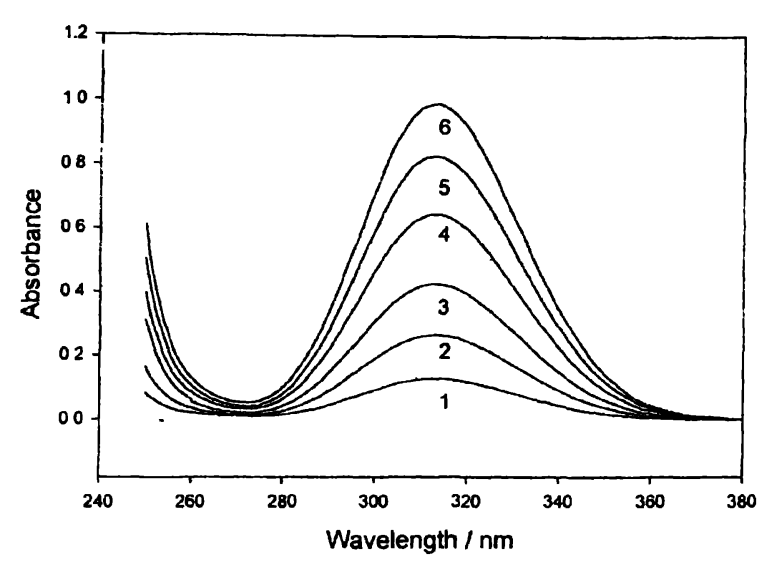

Fig. 4. Spectra of gold(III) at $[\mathrm{HCl}]=0.01 \mathrm{~mol} \mathrm{dm}^{-3}$. Plot of absorbance versus wavelength. Gold(III) cencentrations are (1) 0.30 $\times 10^{-4}$, (2) $0.59 \times 10^{-4}$, (3) $1.04 \times 10^{-4}$, (4) $1.48 \times 10^{-4}$, (5) $1.93 \times 10^{-4}$ and (6) $2.37 \times 10^{-4} \mathrm{~mol} \mathrm{dm}^{-3}$.

Most of the kinetic investigations were carried out spectrophotometrically although few other studies have also been made using different techniques. The reactions when studied spectrophotometrically at lower gold(III) concentrations $\left(\sim 10^{-4} \mathrm{~mol} \mathrm{dm}^{-3}\right)$, the monitoring wavelength was $315 \mathrm{~nm}$ (mostly in case of inorganic substrates). On the other hand when higher concentrations of gold(III) of $\sim 10^{-3} \mathrm{~mol} \mathrm{dm}^{-3}$ were used the reactions (mostly with organic substrates) were followed at $400 \mathrm{~nm}$. This is because of the formation of colloidal gold in the presence of UV light, which complicated the rate measurements, and the formation of colloidal gold increased in the presence of reducing substrate upon exposure to UV light. However, gold(III)-iron(II) reaction was studied ${ }^{16}$ amperometrically using rotating platinum electrode as the indicator electrode and the silver-silver(I) chloride as the reference electrode. A potential of $0.8 \mathrm{~V}$ versus the reference electrode was used. At this potential iron(II) is mass transport controlled and the gold(III) and gold(I) are electro inactive.

\section{References}

1. (a) P. J. Sadler, Gold Bull., 1976, 9, 110; (b) M. Melnik and R. V. Parish, Coord. Chem. Rev., 1986, 70, 157.

2. (a) R. J. Puddephatt, "The Chemistry of Gold", Elsevier, Amsterdam, 1978; (b) "Comprehensive Coordination Chemistry", 1st ed., eds. Sir G. Wilkinson. R. D. Gillard and J. A. McCleverty, Pergamon Press, Oxford, 1987, p. 864.

3. (a) D. I. Nichols and A. S. Charleston, J. Chem. Soc. (A), 1969, 2581; (b) A. D. Westland, Can. J. Chem., 1969. 47, 4135; (c) A. P. Koley, S. Purohit. L. S. Prasad, S. Ghosh and P. T. Manoharan, Inorg. Chem. 1992, 31, 305; (d) A. P.
Koley, P. Nirmala, L. S. Prasad. S. Ghosh and P. T. Manoharan. Inorg. Chem. . 1992, 31, 1764; (e) A. P. Koley, L. S. Prasad, P. T. Manoharan and S. Ghosh, Inorg. Chim. Acta, 1992, 194. 219.

4. (a) C. D. Garner and S. C. Wallwork, J. Chem. Soc. (A), 1970, 3092: (b) F. H. Fry, G. A. Hamilton and J. Turkevich, Inorg. Chem., 1966. 5, 1943: (c) A. J. Edwards and G. R. Jones, J. Chem. Soc. (A), 1969, 1936.

5. (a) C. F. Wieck and F. Basolo, Inorg. Chem.. 1966, 5, 576: (b) C. M. Harris, J. Chem. Soc. 1959, 682; (c) C. M. Harris and T. N. Lockyer, J. Chem. Soc., 1959, 3083.

6. P. J. Sadler, Struct. Bonding, 1976, 29, 171.

7. C. F. Shaw III, Perspect. Biol. Med., 1979, 2, 287.

8. K. C. Dash and H. Schmidbaur, Met. Ions Biol. Syst., 1983, 14, 180.

9. P. J. Sadler and R. E. Sue, Metal Based Drugs, 1994, 1, 107.

10. B. F. G. Johnson and R. Davis, "The Chemistry of Copper, Silver and Gold", Pergamon Press, London, 1975, pp. 729, 153.

11. R. V. Parish, B. P. Howe, J. P. Wright, J. Mack, R. G. Pritchard, R. G. Buckley, A. M. Elsome and S. P. Fricker, Inorg. Chem., 1996, 35, 1659.

12. P. Calamai, S. Carotti, A. Guerri, T. Mazzei, L. Messori, E. Mini, P. Orioli and G. P. Speroni, AntiCancer Drug Des., 1998, 13. 67.

13. C. F. Shaw III, Comments Inorg. Chem., 1989, 8, 233.

14. S. L. Best and P. J. Sadler, Gold. Bull., 1996, 29, 87.

15. (a) E. Gleichmann, D. Schuhmann and $M$. Kubickamuranyi, Eur. J. Pharmacol., 1990, 183, 78; (b) A. J. Canumalla, N. Al-Zamil, M. Phillips, A. A. Isab and C. F. 3rd. Shaw, J. Inorg. Biochem., 2001, 85, 67; (c) S. Fukuzumi, K. Ohkubo, W. E., Z. Ou, J. Shao, K. M. Kadish, J. A. Hutchison, K. P. Ghiggino, P. J. Sintic and M. J. Crossley, J. Am. Chem. Soc., 2003, 125, 14984.

16. K. G. Moodley and M. J. NicoI, J. Chem. Soc., Dalton Trans., 1977, 9993.

17. K. K. Sen Gupta and B. Basu, Transition Met. Chem., $1983,8,3$.

18. (a) K. K. Sen Gupta and B. Basu, Transition Met. Chem., 1983, 8, 6; (b) V. Soni and R. N. Mehrotra, Transition Met. Chem., 2003, 28, 893; (c) S. Mandal, R. N. Bose, J. W. Reed and E. S. Gould, Inorg. Chem. . 1996. 35, 3159.

19. K. K. Sen Gupta, A. Sanyal and P. K. Sen. Transition Met. Chem., 1994, 19. 534.

20. K. K. Sen Gupta, B. Basu, S. Sen Gupta and S. Nandi. Polyhedron, 1983, 2, 983.

21. K. K. Sen Gupta and B. Basu, Polyhedron, 1984, 3, 805. 
Pal et al. : Electron transfer reactions between chloroaurate(III) complexes etc.

22. R. M. Babshet and S. G. Gokavi, Inorg. React. Mech., $2001,3,75$.

23. G. Annibale, L. Canovese, L. Cattealini and G. Natile, J. Chem. Soc., Dalton Trans., 1981, 1093.

24. (a) K. K. Sen Gupta, S. Das and S. Sen Gupta, Transition Met. Chem., 1988, 13, 261; (b) K. Paclawski and K. Fitzner. Metallurgical and Materials Transactions $B, 2004,35 B, 1071$.

25. P. K. Sen. A. Sanyal and K. K. Sen Gupta, Bull. Chern. Soc. Jpn., 1996, 69, 1543.

26. B. S. Maritz and R. Van Eldik, Inorg. Chimica Acta, 1976, 17, 21.

27. B. Pal, P. K. Sen and K. K. Sen Gupta, J. Phy. Org. Chem., 2001, 14, 284.

28. K. K. Sen Gupta, B. Pal and P. K. Sen, Int. J. Chem. Kinet. . 1999, 31, 873.

29. P. K. Sen, B. A. Bilkis and K. K. Sen Gupta, Int. J. Chem. Kinet., 1998, 30, 613.

30. K. K. Sen Gupta, B. Pal and B. A. Begum, Carbohydrate Res., 2001, 330, 115.

31. W. M. Latimer, "The Oxidation States of the Elements and their Potentials in Aqueous Solution", 2nd ed., Prentice Hall, NJ, 1961, pp. 195, 196.

32. "CRC Handbook of Chemistry \& Physics", ed. R. C. Weast, 67th ed., CRC Press, Florida, 1986-1987, p. D151.

33. (a) G. M. Schmid and M. E. Curley-Fiorino, "Encyclopedia of Electrochemistry of the Elements", ed. A. J. Bard, Dekker, New York, 1975, Vol. IV, Chap. IV-3; (b) L. H. Skibsted and J. Bjerrum, Acta Chem. Scand., Ser. $A, 1977,31,155$.

34. W. Robb, Inorg. Chem., 1967, 6, 382.

35. H. G. Forsberg, H. Widdel and L. G. Erwall, J. Chem. Ed., 1960, 37, 44.

36. (a) L. Drougge and L. I. Elding, Inorg. Chem., 1987, 26, 1073; (b) A. Peloso, Coord. Chem. Rev., 1975, 16, 95.

37. A. N. Gidd, M. D. Bhaud and G. S. Gokavi, Transition Met. Chem., 1995, 20, 367.

38. K. K. Sen Gupta, A. Sanyal and S. Ghosh, J. Chem. Soc. (Dalton), 1995, 1227.

39. (a) E. T. Borish and L. J. Kirschenbaum, J. Chem. Soc. (Dalton), 1983, 749; (b) L. J. Kirschenbaum, J. Inorg. Nucl. Chem., 1976, 38, 881.

40. B. S. Maritz, R. van Eldik and J. A. Van den Berg, J. S. African Chem. Inst., 1975, 28, 14.

41. B. S. Maritz and R. van Eldik, J. Inorg. Nucl. Chem., 1977, 39, 1033.

42. (a) W. J. Louw and W. Robb, Inorg. Chim. Acta,
1969, 3, 29; (b) P. van Z. Bekker, W. J. Louwand W. Robb, Inorg. Chim. Acta. 1972. 6, 564.

43. W. J. Louw and W. Robb, Inorg. Chim. Acta, 1969, 3, 303.

44. D. de Filippo, F. Devillauova and C. Preti, Inorg. Chim. Acta, 1971, 5. 103.

45. J. Zou. Z. Guo, J. A. Parkinson, Y. Chen and P. Sadler, Chem. Commun.. 1999, 1359.

46. (a) L. R. Milgrom, J. Chem. Res. (S). 1986, 452; (b) G. Marcon, L. Messori, P. Orioli, M. A. Cinellu and G. Minghetti, Eur. J. Biochem., 2003, 270, 4655.

47. A. G. Fadnis and T. J. Kemp, J. Chem. Soc., Dalton Trans., 1989, 1237.

48. S. Komiya, T. A. Albright, R. Hoffman and J. K. Kochi, J. Am. Chem. Soc., 1977, 99, 8440.

49. A. Johnson and R. J. Puddephatt, J. Chem. Soc., Dalton Trans., 1975, 115.

50. R. Kaptein, P. W. N. M. van Leevwean and R. Wis. J. Chem. Soc., Chem. Commun., 1975, 568.

51. E. E. Conn and P. K. Stumpf, "Outlines of Biochemistry", 4th ed., John Wiley \& Sons., New York, 1990, pp. 279-316.

52. A. White, P. Handler, E. L. Smith and De Witt Stellen, "Principles of Biochemistry", 2nd ed., McGraw Hill, New York, 1959, pp. 380-445.

53. B. Capon, Chem. Rev., 1969, 69, 407.

54. K. K. Sen Gupta, A. Tarafdar and A. Mahapatra, J. Chem. Res. (S), 1987, 306.

55. K. K. Sen Gupta, S. Sen Gupta, U. Chatterjee, A. Tarafdar, T. Samanta and U. Sharma, Carbohydrate Res., 1983, 117, 81.

56. G. St. Nikolov, Inorg. Chem. Acta, 1971, 5, 559.

57. W. C. E. Higginson, D. Suttan and P. Wright, J. Chem. Soc., 1953, 1380.

58. B. B. Pal and K. K. Sen Gupta, Inorg. Chem.. 1975, 14, 2268

59. K. K. Sen Gupta, B. B. Pal and D. C. Mukherjee, J. Chem. Soc. (Dalton), 1974, 224.

60. K. K. Sen Gupta, J. K. Chakladar, B. B. Pal and D. C. Mukherjee, J. Chem. Soc.(Perkin), 1973, 926.

61. H. Schmidbaur and K. C. Das, Adv. Inorg. Chem. Radiochem., 1982, 25, 239.

62. H. van Willigen and J. G. M. van Rens, Chem. Phys. Lett. , 1968, 2, 283.

63. J. H. Waters and H. B. Gray, J. Am. Chem. Soc., $1965,87,3534$

64. T. Vaurgard and S. Akerstrom. Nature, 1965, 184, 183. 


\section{J. Indian Chem. Soc., Vol. 83, August 2006}

65. L. F. Lindoy and S. F. Livingstone, Inorg. Chem., 1968, 7, 1149.

66. J. L. Corbin and D. F. Work, Can. J. Chem., 1974, 52, 1054.

67. A. P. Koley, S. Purohit, S. Ghosh, L. S. Prasad and P. T. Manoharan, J. Chem. Soc. (Dalton Trans.), 1988, 2607.

68. J. C. Bailer, "Comprehensive Inorganic Chemistry", Pergamon Press, Oxford, 1973, p. 141.
69. B. M. Gordon, L. L. Williams and N. Sutin, J. Am. Chem. Soc., 1961, 83, 2061.

70. M. H. Ford-Smith and N. Sutin. J. Am. Chern. Soc., $1961,83,1830$.

71. A. A. Frost and R G. Pearson, "Kinetics and Mechanism", Wiley Eastern. New Delhi, 1970, p. 143.

72. A. K. Gangopadhayay and A. Chakravorty, J. Chem. Phys., 1961, 35, 2206. 